\title{
Transgenic Models of Alzheimer's Disease: Learning from Animals
}

\author{
Tara L. Spires and Bradley T. Hyman \\ Harvard Medical School, Massachusetts General Hospital; and Department of Neurology, MassGeneral Institute for \\ Neurodegenerative Disease, Charlestown, Massachusetts 02129
}

\begin{abstract}
Summary: As the scope of the problem of Alzheimer's disease (AD) grows due to an aging population, research into the devastating condition has taken on added urgency. Rare inherited forms of $\mathrm{AD}$ provide insight into the molecular pathways leading to degeneration and have made possible the development of transgenic animal models. Several of these models are based on the overexpression of amyloid precursor protein (APP), presenilins, or tau to cause production and accumulation of amyloid- $\beta$ into plaques or hyperphosphorylated tau into neurofibrillary tangles. Producing these characteristic neuropathological lesions in animals causes progressive neurodegeneration and in some cases similar behavioral disruptions to
\end{abstract}

those seen in $\mathrm{AD}$ patients. Knockout models of proteins involved in $\mathrm{AD}$ have also been generated to explore the native functions of these genes and examine whether pathogenesis is due to loss of function or toxic gain of function in these systems. Although none of the transgenic lines models the human condition exactly, the ability to study similar pathological processes in living animals have provided numerous insights into disease mechanisms and opportunities to test therapeutic agents. This chapter reviews animal models of AD and their contributions to developing therapeutic approaches for AD. Key Words: Amyloid, tau, transgenic, senile plaque, neurofibrillary tangle.

\section{ALZHEIMER'S DISEASE CLINICAL FEATURES, NEUROPATHOLOGY, AND GENETICS}

Alzheimer's disease (AD), the leading cause of dementia, currently affects 12 million people worldwide; 4.5 million of these are in America alone, a striking figure that is predicted to almost triple by $2050 .{ }^{1,2}$ Transgenic animal models of $\mathrm{AD}$ provide an excellent tool for investigating pathogenic mechanisms and treatments. Here, we review these models and their contributions to the field. To begin, we will briefly discuss the symptoms and pathology of Alzheimer's disease that transgenic models are designed to emulate.

The first and most common symptom of AD is memory loss. Patients also undergo general cognitive decline including temporal and geographic disorientation, impairment of judgment and problem solving, and deterioration of language abilities. ${ }^{3}$ Behavioral and personality

Address correspondence and reprint requests to Bradley T. Hyman, Massachusetts General Hospital, Department of Neurology, Alzheimer's Disease Research Laboratory, 114 16th Street, Room 2009, Charlestown, MA 02129. E-mail: bhyman@partners.org or tspires@ partners.org. changes also occur until the end stages of the disease when troublesome behaviors disappear along with most personality traits. ${ }^{4,5}$ In the severe stages of the disease, motor complications often develop, ${ }^{6,7}$ which along with the dementia, leave people completely bedridden and dependent on caregivers.

\section{What is wrong in the Alzheimer brain?}

In 1907, in the first report of a patient with the disease that later came to be named after him, Alois Alzheimer described senile plaques and neurofibrillary tangles $(\mathrm{NFTs})^{8}$ - the two lesions that pathologists still use to make the histological diagnosis of AD. Since these original descriptions, great advances have been made in our understanding of these lesions and other abnormalities have been identified and described in the AD brain. In 1927, Divry discovered that Congo red-stained senile plaques in the $\mathrm{AD}$ brain exhibit birefringence and described plaques as an extracellular aggregation of amyloid $^{9}$ whose molecular identity was established 57 years later by Glenner. ${ }^{10}$ In 1987, Kang et al. ${ }^{11}$ showed that the amyloid in senile plaques is derived from the amyloid precursor protein (APP). Plaques are not uniform in nature, there are commonly two types: diffuse plaques con- 
taining mainly nonstructured amyloid, and dense, fibrillar plaques. Dense-cored fibrillar plaques are often associated with a halo of dystrophic neurites. ${ }^{12-14}$

Plaques form in the neocortex, hippocampus, and amygdala of the $\mathrm{AD}$ brain. In the hippocampus, the dentate gyrus contains a layer of neuritic plaques. ${ }^{15}$ Within the neocortex, layers II and III are most susceptible to plaque formation, and limbic and association cortices are more susceptible than primary sensory cortex. ${ }^{16-19}$ Plaques usually form first in basal neocortex then spread to the hippocampal formation and adjoining cortical areas. ${ }^{20}$ The most popular hypothesis regarding plaque formation is that neuritic plaques develop from a preceding diffuse plaque. ${ }^{12}$ Evidence from analysis of plaque structure and formation in $\mathrm{AD}$ and transgenic mice indicates that plaques form by reversible aggregation of $\mathrm{A} \beta$ in clusters. ${ }^{21,22}$

NFTs, the other classic hallmark of AD pathology, are intraneuronal lesions of paired helical filaments ${ }^{23}$ made of hyperphosphorylated tau protein. ${ }^{24}$ Similar deposits of paired helical filament (PHF) tau in axons and dendrites form, called neuropil threads. Tangles are found in the subiculum, cornu ammonis 1 region of the hippocampus (CA1), entorhinal cortex and neocortex, ${ }^{15,25}$ and also in several subcortical areas including the amygdala, nucleus basalis of Meynert, ventral tegmental area, dorsal raphe, olfactory bulb, and some thalamic and hypothalamic nuclei. ${ }^{26}$ Braak and Braak ${ }^{20}$ characterized the frequency of occurrence of tangles in different brain regions at different ages and determined that tangles form first in the transentorhinal region and spread through the entorhinal cortex, hippocampus, association cortex and sensory cortex. This progression directly disrupts the temporal lobe memory system, ${ }^{27}$ doubtless contributing to memory loss. Indeed, NFT density correlates with disease duration $^{19}$ and severity of dementia. ${ }^{28-30}$

Extensive neuron loss occurs in vulnerable areas of the AD brain closely mirroring the progression of NFT formation. Large-scale loss of neurons further disrupts neuronal circuitry and must also contribute to cognitive decline seen in AD. Pyramidal neurons that extend long corticocortical projections are particularly vulnerable, and their death disrupts connections between association cortices. ${ }^{31}$ For example, up to $90 \%$ of large pyramidal neurons in prefrontal cortex are lost by the end stages of $\mathrm{AD}^{32}$ The circuitry connecting the entorhinal cortex and the hippocampal formation is also decimated in ADthis pathway supplies information from many association cortices for processing in the hippocampus and is believed to play a crucial role in memory. ${ }^{33}$ Even in mild $\mathrm{AD}, 50 \%$ of the neurons in layer II of entorhinal cortex can be lost, and in severe AD cases, almost all of the neurons in this layer have died. ${ }^{34}$ In the CA1 region of the hippocampus, around $70 \%$ of neurons die during the progression of $\mathrm{AD}{ }^{35}$
Neurons that remain in the AD brain undergo extensive morphological changes: dystrophic neurites form, dendritic and axonal trees are remodeled, and synapse and dendritic spine densities change. ${ }^{36}$ These changes alter connectivity in circuits responsible for memory and cognition, probably contributing to AD symptoms. Indeed, synapse loss strongly correlates with cognitive decline in patients. ${ }^{37-39}$

\section{Molecular genetics of $\mathrm{AD}$}

The amyloid cascade hypothesis holds that altered amyloid processing and aggregation constitute the key pathogenic factor in $\mathrm{AD}$, and that the rest of the disease results from amyloid-induced changes (FIG. 1). ${ }^{40}$ The strongest support for the amyloid hypothesis has come from the discovery that all of the genes implicated in familial AD increase the production or aggregation of $\mathrm{A} \beta$. Environmental conditions and genetic factors both appear to play important roles in the complex etiology of AD. The majority of Alzheimer cases seem to be sporadic or to result from complex interactions of several genes. Nevertheless, a minority of $\mathrm{AD}$ cases $(<1 \%)$ result from autosomal dominant inheritance of an agedependent trait with high penetrance. ${ }^{41,42}$ Identification of the genes involved in these rare familial cases of $\mathrm{AD}$ provides a powerful tool for elucidation of disease mechanisms and production of transgenic animal models as will be discussed below. The first genetic mutation associated with familial $\mathrm{AD}$ was in the amyloid precursor protein (APP) gene. Suspicion of the involvement of APP in familial AD arose since the gene resides on chromosome $21^{11}$ and people with Down's syndrome (who have an extra copy of chromosome 21) develop neuropathological attributes of AD by age $40 .{ }^{43}$ Genetic linkage studies also suggested the involvement of a locus near the APP gene on chromosome 21 in familial AD (FAD). ${ }^{44,45}$ The first missense mutation confirmed in the APP gene in FAD was found in a British family ${ }^{46}$ and confirmed in a Japanese family in $1991 .{ }^{47}$ Since then, 20 pathological mutations in APP have been identified. Most of these are near the proteolytic cleavage sites involved in $\mathrm{A} \beta$ production.

Mutations in APP do not account for all cases of familial AD. In the mid 1990s, further genetic linkage studies uncovered mutations in presenilin 1 on chromosome $14^{48-50}$ and presenilin 2 on chromosome $1^{51,52}$ Presenilin forms the active site of the $\gamma$-secretase complex involved in the production of $\mathrm{A} \beta{ }^{53}$ Cleavage of APP by $\gamma$ and $\beta$-secretases produces the $\mathrm{A} \beta$ peptide which aggregates into plaques. ${ }^{54}$

Genetic risk factors also exist for nonfamilial, sporadic cases of AD. Apolipoprotein E (ApoE) gene polymorphisms appear to be involved in late-onset familial aggregated cases of $\mathrm{AD}$. In particular the $\epsilon 4$ allele of ApoE increases the risk of developing $\mathrm{AD},{ }^{55,56}$ whereas the $\epsilon 2$ 


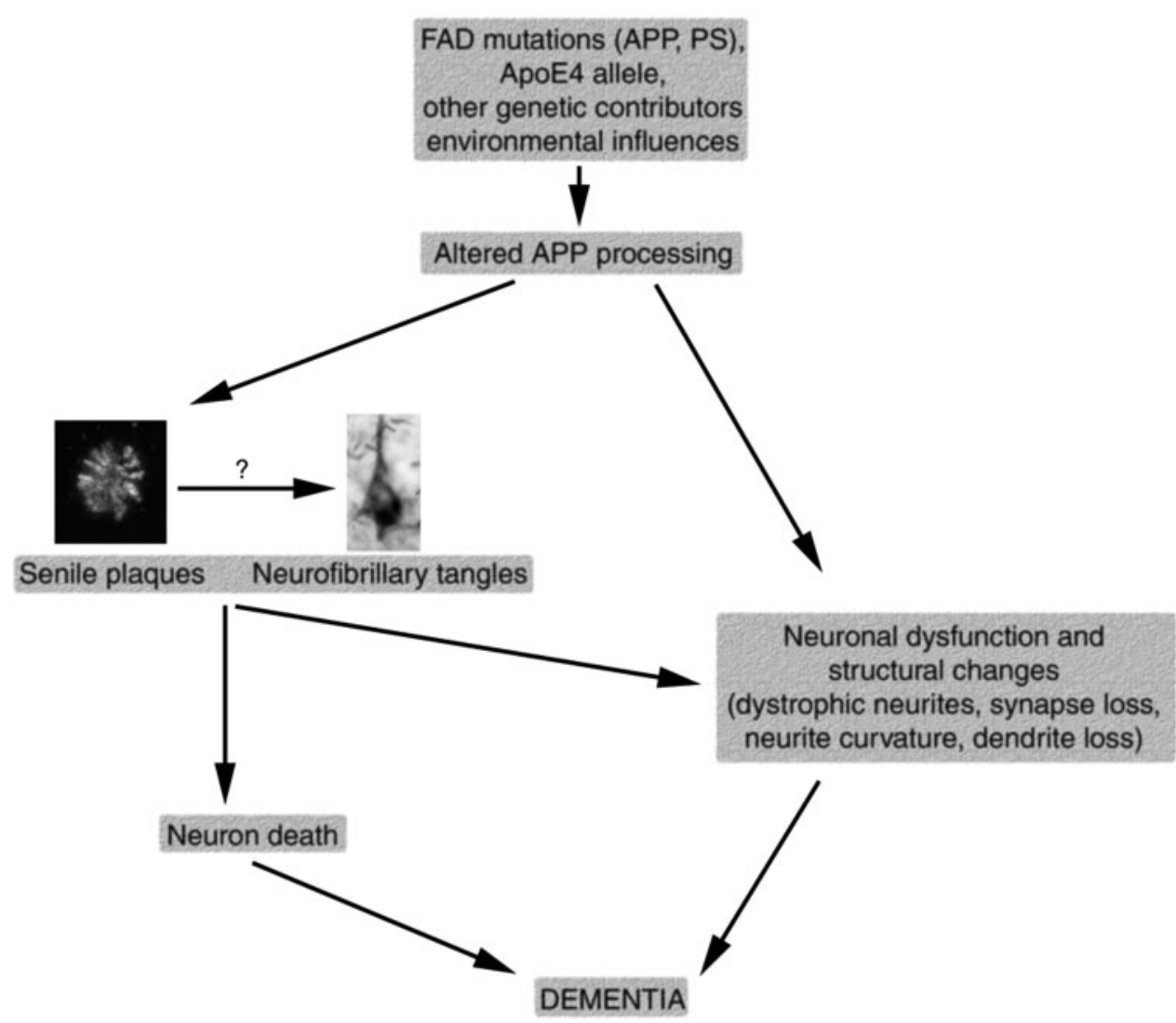

FIG. 1. The amyloid hypothesis of Alzheimer's pathogenesis suggests that altered processing of APP due to genetic and environmental influences causes a cascade of events leading to neuronal dysfunction and death.

allele appears protective. ${ }^{57} \mathrm{ApoE}$ can bind $\mathrm{A} \beta^{58}$ and localizes to senile plaques, ${ }^{59}$ raising the possibility that this protein plays a role in $\mathrm{A} \beta$ clearance.

To date, no mutations in the tau gene have been associated with familial AD. However, NFT pathology appears to play an important role in $\mathrm{AD}$ progression, so animal models to study tangle formation are useful in the context of AD research as well as studies on tauopathies. Mutations in the tau gene on chromosome 17 have been associated with a class of frontotemporal dementias termed frontotemporal dementia with parkinsonism linked to chromosome 17 (FTDP-17). These tauopathies present with tau aggregations in neurons and glia without any amloid deposits. ${ }^{60}$

\section{AMYLOID PATHOLOGY MOUSE MODELS}

The first transgenic models of AD came from overexpression of amyloid precursor protein in an attempt to reproduce amyloid pathology. As discussed above, the popular amyloid hypothesis predicts that altered amyloid processing should result in Alzheimer-like pathology. Amyloid precursor protein is processed in two pathways, one fibrillogenic that leads to plaque formation and the other nonfibrillogenic (FIG. 2). Mutations of APP are associated with familial $\mathrm{AD}$, and amyloid- $\beta$, a degrada-

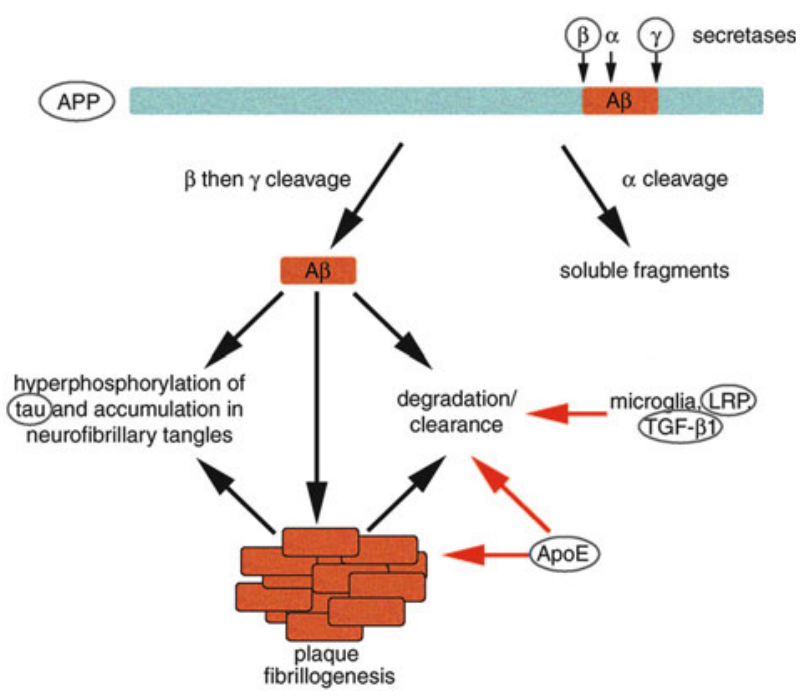

FIG. 2. Amyloid precursor protein cleavage by $\beta$ - and $\gamma$-secretases leads to the production of $A \beta$, the primary component of senile plaques in $\mathrm{AD}$. Circled molecules have been used in transgenic mouse models to study AD pathogenesis. Overexpression of APP causes plaque formation in mice and coexpressing either $\beta$ - or $\gamma$-secretase components with APP accelerates plaque formation. $A \beta$ increases neurofibrillary tangle formation in tau overexpressing mice. Studies of ApoE knockout and transgenic mice indicate that this molecule may be involved in both $A \beta$ deposition and clearance. Reducing LRP in mouse models increases $A \beta$ deposition, indicating a role for LRP in clearance or degradation of $A \beta$. Similarly, overexpression of TGF- $\beta 1$ reduces plaque burden in APP mice implicating it in A $\beta$ clearance. 
TABLE 1. Transgenic Rodent Models of AD Pathology

\begin{tabular}{|c|c|c|c|c|c|c|c|c|c|}
\hline Name & $\begin{array}{c}\text { Gene(s) } \\
\text { Overexpressed }\end{array}$ & Promoter & $\begin{array}{l}\text { Neuropathology } \\
\text { Plaques }\end{array}$ & P-tau & NFT & Cell Loss & $\begin{array}{l}\text { Memory } \\
\text { Deficits }\end{array}$ & $\begin{array}{l}\text { Age of Onset (of } \\
\text { Pathology) }\end{array}$ & References \\
\hline PDAPP mice & $\begin{array}{l}\text { APP minigene, V717F } \\
\text { mutation }\end{array}$ & $P D G F \beta$ & Yes & Yes & No & No & Yes & 6-8 months & $63,67-69$ \\
\hline $\operatorname{Tg} 2576$ mice & APP Swe cDNA (695) & Hamster $\operatorname{Pr} P$ & Yes & Yes & No & No & Yes & 9-11 Months & $72,75,76$ \\
\hline APP23 mice & APP Swe cDNA (751) & Murine Thyl & Yes & Yes & No & Yes (CA1) & Yes & 6 Months & $77-81$ \\
\hline TgCRND8 mice & $\begin{array}{l}\text { APP cDNA Swe and } \\
\text { V717F mutations }\end{array}$ & Syrian hamster $\operatorname{Pr} P$ & Yes & $\mathrm{nr}$ & No & $\mathrm{nr}$ & Yes & 3 Months & 84,85 \\
\hline $\begin{array}{l}\text { APPSwe } \mathrm{TgC} 3-3 \\
\text { mice }\end{array}$ & APP cDNA (695) Swe & Murine $\operatorname{Pr} P$ & Yes & $\mathrm{nr}$ & $\mathrm{nr}$ & $\mathrm{nr}$ & $\mathrm{nr}$ & 18 Months & 82,83 \\
\hline PSAPP mice & $\begin{array}{l}\operatorname{Tg} 2576 \text { and PSI } \\
\text { M146L }\end{array}$ & Hamster $\operatorname{Pr} P, P D G F \beta$ & Yes & Yes & $\mathrm{nr}$ & Minor & Yes & 6 Months & $88-90$ \\
\hline $\operatorname{Tg} 478 / 1116 / 11587$ rat & $\begin{array}{l}\text { APP Swe, APP Swe } \\
\text { and V717F, PS1, } \\
\text { M146V }\end{array}$ & $\begin{array}{l}\text { Rat synapsin 1, } P D G F \beta \text {, } \\
\quad \text { Rat synapsin I }\end{array}$ & Yes & $\mathrm{nr}$ & $\mathrm{nr}$ & $\mathrm{nr}$ & $\mathrm{nr}$ & 9 Months & 93 \\
\hline ALZ7 mice & $4 \mathrm{R}$ tau & Human Thyl & No & Yes & No & No & $\mathrm{nr}$ & - & 122 \\
\hline ALZ17 mice & $4 \mathrm{R}$ tau & Murine Thyl & No & Yes & No & No & $\mathrm{nr}$ & - & 124 \\
\hline 7TauTg mice & $3 \mathrm{R}$ tau & Murine $\operatorname{PrP}$ & No & Yes & Yes & $\mathrm{nr}$ & $\mathrm{nr}$ & 18-20 Months & 127 \\
\hline JNPL 3 mice & 4R tau P301L & Murine $\operatorname{Pr} P$ & No & Yes & Yes & Yes & Yes & 5 Months & 130,131 \\
\hline pR5 mice & $4 \mathrm{R}$ tau $\mathrm{P} 301 \mathrm{~L}$ & Murine Thyl & No & Yes & Yes & Yes & $\mathrm{nr}$ & 8 Months & 132 \\
\hline TAPP mice & $\operatorname{Tg} 2576 x$ JNPL3 & Hamster $\operatorname{Pr} P$, Murine $\operatorname{Pr} P$ & Yes & Yes & Yes & $\mathrm{nr}$ & $\mathrm{nr}$ & 6 Months & 136 \\
\hline $3 x T g-A D$ & $\begin{array}{l}\text { APP (Swe), PS1 } \\
\text { (M146V), tau } \\
\text { (P301L) }\end{array}$ & $\begin{array}{l}\text { Murine Thyl (PS1 } \\
\text { knockin) }\end{array}$ & Yes & Yes & Yes & $\mathrm{nr}$ & $\mathrm{nr}$ & 3 Months & 137,138 \\
\hline
\end{tabular}

$\mathrm{nr}=$ not reported; Swe $=$ Swedish mutation; P-tau $=$ phosphorylated tau immunoreactivity

tion product of APP, accumulates in senile plaques, dystrophic neurites, and synaptic terminals in the $\mathrm{AD}$ brain. ${ }^{40}$ Thus, many groups worked under the theory that overexpressing human APP (wild-type and with FADassociated mutations) or fragments of APP under neuron specific promoters might result in amyloid pathology similar to that seen in AD. After largely unsuccessful attempts to create a mouse model of $\mathrm{AD}$ in the early $1990 \mathrm{~s},{ }^{61,62}$ the field took off, and to date, around a dozen mouse models exist that develop amyloid pathology due to overexpression of APP variants (Table 1).

Games and colleagues ${ }^{63}$ reported a convincing mouse model of AD, the PDAPP mouse, in 1995. PDAPP mice overexpress human APP cDNA with portions of APP introns 6-8 and with valine at residue 717 substituted by phenalalanine- one of the FAD-associated mutationsunder the control of a platelet-derived growth factor $\beta$ (PDGF $\beta)$ promoter. These mice, unlike the earlier APP models controlled by an NSE promoter, ${ }^{64-66}$ express very high levels of APP protein $(\sim 10$-fold higher than endogenous APP), and they develop more Alzheimer-like neuropathology, including extracellular diffuse and neuritic plaques, dystrophic neurites, gliosis, and loss of synapse density. ${ }^{63,67}$ Notably, plaque formation in these mice proceeds from the hippocampus (at 6-8 months) to cortical and limbic areas (8 months) in a progressive manner showing regional specificity like that seen in $\mathrm{AD}$ pathology. ${ }^{63,68}$ Furthermore, amyloid burden and memory impairment assessed using a modified Morris water maze task increase with aging. ${ }^{69}$ The amyloid pathology in PDAPP mice is strikingly similar to that observed in AD. Ultrastructural comparisons reveal similar amyloid fibril size, similar plaque-associated dystrophic neurites containing synaptic components and neurofibrils, association of microglia with plaques, and phosphorylation of neurofilaments and tau protein in neurites in aged mice (18 months). ${ }^{67,70}$ However, these neurodegenerative alterations are not accompanied by paired-helical filament formation, and stereological analysis by Irizarry et al. ${ }^{68}$ revealed no global neuronal loss in the entorhinal cortex, CA1, or cingulate cortex through 18 months of age. Loss of neurons in the immediate vicinity of dense-cored plaques, however, was observed mimicking observations in human $\mathrm{AD} .^{71}$

In 1996, Hsiao et al. ${ }^{72}$ published another APP overexpressing mouse model of AD, the Tg2576 line. These mice are transgenic for human APP cDNA with the double Swedish mutation (K670N and M671L) under the control of the hamster prion protein promoter $(\operatorname{Pr} P)$. Heterozygous $\mathrm{Tg} 2576$ mice produce APP at 5.5-fold over endogenous levels and develop diffuse and neuritic plaques in the hippocampus, cortex, subiculum, and cerebellum at around 9-11 months of age similar to those seen in AD and PDAPP mice (FIG. 3). In spontaneous alternation and water maze tasks, Tg2576 mice show subtle age-related memory deficits starting at around 8 months of age. ${ }^{72}$ They also have an age-dependent electrophysiological phenotype at older ages characterized by impaired induction of LTP in the hippocampus in vitro and in vivo. ${ }^{73}$ In cortex, synaptic integration is also disrupted in vivo. ${ }^{74}$ These functional disruptions may underlie some of the observed memory deficits. Plaques in Tg2576 mice are associated with dystrophic neurites and gliosis, but without global loss of synapses or neurons in CA1. ${ }^{75}$ Recently, Lanz et al. ${ }^{76}$ reported that dendritic spine density decreases in CA1 of both PDAPP and $\operatorname{Tg} 2567$ mice before plaque deposition, demonstrating that these models both emulate some of the disrupted synaptic circuitry seen in AD.

APP23 mice, developed at Novartis, overexpress hu- 

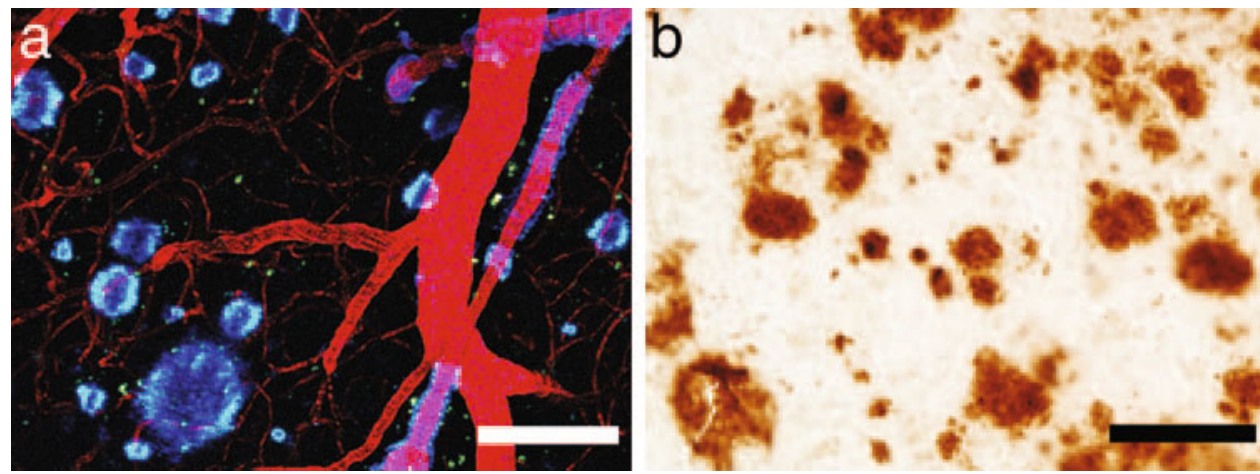

FIG. 3. Overexpression of mutant human APP in Tg2576 mice (a) causes age-related deposition of amyloid into plaques and cerebral amyloid angiopathy (labeled blue with methoxy X-O4; blood vessels are filled with Texas Red). The amyloid pathology in these mice closely resembles that seen in the AD brain as shown with 10D5 immunostaining (b). Scale bars: $50 \mu \mathrm{m}$.

man APP cDNA with the Swedish mutation under control of the murine Thyl.2 promoter. These mice develop both amyloid plaques and cerebral amyloid angiopathy starting at around 6 months of age. ${ }^{77}$ Similarly to the previously described models, APP23 mice develop memory deficits as assessed by behavioral tests. ${ }^{78-80}$ Unlike the PDAPP and Tg2576 lines, neuron loss of $14 \%$ was reported in the CA1 of the APP23 mice, although no loss was detected in the cortex. ${ }^{81}$ Another APP overexpressing mouse line with the Swedish mutation, developed by Borchelt et al. ${ }^{82,83}$ does not develop plaques until 18 months (line APP Swe C3-3). The transgene is driven by a different promoter (mouse prion promoter) and is on a different background strain $(\mathrm{C} 57 \mathrm{BL} / 6-\mathrm{C} 3 \mathrm{H})$ from the $\mathrm{Tg} 2576$ and APP23 models mentioned above that have earlier onset of amyloid deposition.

Expression of both the Swedish mutation and the V717F mutation driven by the Syrian hamster prion promoter (TgCRND8 mouse model) causes early deposition of amyloid in plaques and premature death dependent on background strain, ${ }^{84,85}$ indicating the importance of genetic background on the effects of APP overexpression. TgCRND8 mice also perform poorly in the water maze indicating memory deficits.

\section{Interactions of presenilins and APP}

The above models clearly show that overexpression of human APP with familial AD-associated mutations can recapitulate much of the amyloid pathology seen in $\mathrm{AD}$; however, APP mutations cause only a small fraction of the already minute number of FAD cases. Mutations in presenilins 1 and 2 also cause familial $\mathrm{AD},{ }^{42}$ probably by altering the processing of APP to favor the production of $\mathrm{A} \beta$ and in particular the fibrillogenic $\mathrm{A} \beta_{42}$ species (FIG. 2). FAD-associated presenilin mutations have been used to generate animal models. Overexpression of either M146L or M146V FAD-associated mutations under the PDGF $\beta$ promoter cause a selective increase in $\mathrm{A} \beta_{42}$ production, whereas overexpression of wild-type PS1 does not change $\mathrm{A} \beta_{42}$ levels. ${ }^{86}$ Expression of the FAD- linked PS1 variant with mutation A246E does not induce amyloid pathology in mice, although it does elevate the $\mathrm{A} \beta_{42} / \mathrm{A} \beta_{40}$ ratio in cell culture. ${ }^{82,83}$ PS2 overexpressing mice similarly fail to develop amyloid pathology. ${ }^{87}$ Crossing mutant PS1-overexpressing mice with the $\mathrm{Tg}$ C3-3 APP line increases the $\mathrm{A} \beta_{42} / \mathrm{A} \beta_{40}$ ratio in the brain and accelerates amyloid deposition such that plaques develop by 12 months of age instead of $18 .^{82,83}$ Similarly, expression of a PS1 M146L, L286V transgene in TgCRND8 mice also accelerated amyloid deposition from 3 months to 1 month of age. ${ }^{85}$

Crossing Tg2576 mice with PS1 M146L mutant mice (PSAPP model) also causes an elevation of $\mathrm{A} \beta_{42} / \mathrm{A} \beta_{40}$ levels and an acceleration of amyloid deposition evident by 6 months of age compared with 9 months in Tg2576 mice. ${ }^{88}$ Stereological investigation of the hippocampus and frontal cortex of these mice indicate that there is still no dramatic cell loss despite the increased severity of the model ${ }^{89}$ Behavioral studies also indicate that this crossbreed has impaired performance on the Y-maze by 3 months of age- before amyloid deposition. ${ }^{88,90}$

Evidence that PS1 coexpression with APP accelerates plaque deposition and that PS1 expression alone is not sufficient to induce amyloid pathology supports the role for PS1 as a modifying gene. FAD-associated mutations of presenilins cause an increased probability of producing the highly fibrillogenic 42 amino acid version of $A \beta$ instead of the less harmful 40 -amino acid peptide. This would make presenilins promising drug targets to decrease amyloid deposition in $\mathrm{AD}$; however, presenilin 1 knockout mice are not viable and develop a skeletal and CNS phenotype,${ }^{91}$ indicating the importance of this gene during development. Overexpression of A246E mutant PS1 can rescue the knockout phenotype and still causes an elevation in $\mathrm{A} \beta$ levels. ${ }^{92}$ Removing presenilin 2 is not as harmful as presenilin 1-PS2 knockout mice are viable but develop pulmonary fibrosis and hemorrhage with age. $^{87}$ 
Cephalon has recently developed an APP/PS1 triple transgenic rat model of AD with time course and amyloid deposition similar to that seen in Tg2576 mice. ${ }^{93}$ Other transgenic rat models have been developed, ${ }^{94,95}$ but the Cephalon rat is the first to show plaque pathology. This model may prove very useful for research because rats are better subjects than mice in several types of experiments such as behavioral testing of cognitive function and electrophysiological recordings.

\section{Other APP-interacting genes: ApoE, lipoprotein receptor-related protein, and $\beta$-site APP cleaving enzyme 1}

The strongest evidence for a genetic contributor to late-onset familial and sporadic AD comes from studies showing that approximately $64 \%$ of AD cases are associated with the presence of the ApoE $\epsilon 4$ allele. ${ }^{55,58}$ In contrast, ApoE $\epsilon 2$ allele appears to be protective because there is a decreased frequency of this allele in AD patients. ${ }^{96}$ The ApoE gene on chromosome 19 encodes for a secreted protein involved in cholesterol transport, uptake, and redistribution, ${ }^{97-99}$ and both ApoE and its receptor, the low-density lipoprotein receptor-related protein (LRP), are found in plaques in AD. ${ }^{100,101}$ Rodent models of the role of ApoE in AD include ApoE knockout mice, ApoE overexpressing mice, and mice expressing specific alleles of ApoE, and combinations of these models with other AD mouse lines.

ApoE knockout mice have decreased synaptophysin and microtubule-associated protein 2 staining, ${ }^{102}$ supporting a role for ApoE in the maintenance of synapses and dendrites during aging. Accompanying the neurodegenerative effects of the ApoE knockout are behavioral deficits that can be rescued by infusing recombinant ApoE. ${ }^{103,104}$ These results support a role for ApoE in neuroprotection. Evidence also exists for the involvement of ApoE in both $\mathrm{A} \beta$ fibrillization and clearance. ${ }^{105}$ Crossing ApoE knockout mice with PDAPP or Tg2576 mice reduces plaque deposition and almost completely prevents both the dense, thioflavine $\mathrm{S}$ (thioS)-positive plaques and neuritic degeneration normally associated with these dense plaques. ${ }^{105-109}$ Furthermore, in PDAPP mice, the ApoE null background induces a redistribution of $\mathrm{A} \beta$ deposition, ${ }^{110}$ indicating a role for $\mathrm{ApoE}$ in the anatomical specificity of amyloid deposition. ${ }^{105}$ On an ApoE null background, CAA and hemorrhage are also reduced. $^{111}$

In APP-expressing mice on an ApoE null background, overexpression of ApoE3 or ApoE4 under the astrocytespecific GFAP promoter "rescues" A $\beta$ deposition in dense, neuritic plaques that are absent in ApoE knockout mice expressing APP. ${ }^{109}$ ApoE4 expression induced a 10-fold higher density of thioflavin-S-positive plaques (which are associated with dystrophic neurites) than expression of ApoE3, ${ }^{109}$ indicating an isoform-specific role of ApoE in plaque formation. Recent knockin mouse models of ApoE expressing human alleles under endogenous regulatory elements crossed with R1.40 APP overexpressing mice resulting in APP + ApoE expressing mice. These had increased brain $\mathrm{A} \beta$ levels (compared with APP-only expressing mice) regardless of whether ApoE allele was $\epsilon 2, \epsilon 3$, or $\epsilon 4 .^{112}$ Overexpressing ApoE2 in both PDAPP and Tg2576 mice ameliorates amyloidinduced dendritic spine loss, ${ }^{76}$ providing a mechanism by which the ApoE2 allele might exert its protective effect in AD.

LRP, an apolipoprotein receptor, regulates cellular A $\beta$ trafficking, and associates with amyloid plaques in AD. ${ }^{101}$ Receptor-associated protein (RAP) knockout mice provide an in vivo model of decreased LRP expression because RAP is required for LRP folding and trafficking. When crossed with APP mice, the reduction in LRP doubled the amount of $\mathrm{A} \beta$ deposited and increased dendritic degeneration. ${ }^{113}$ These results support a protective role for LRP in the development of amyloid pathology, possibly through amyloid clearance.

To form A $\beta$, APP must be cleaved by both $\gamma$-secretase and $\beta$-secretase. As seen above, mutations in presenilins, the catalytic component of the $\gamma$-secretase complex, can cause familial AD and amyloid pathology in transgenic mice. There has also been intense interest in $\beta$-secretase as a drug target and possible contributor to AD pathology. In 2001, Luo et al. ${ }^{114}$ established BACE1 ( $\beta$-site APP cleaving enzyme 1 ) as the major $\beta$-secretase in vivo by generating BACE1 knockout mice that do not produce $A \beta$ - even when crossed with TG2576 APP overexpressing mice. These knockouts are viable and fertile, indicating that BACE may be a safer drug target than presenilins. Independently generated BACE1 knockout mice confirmed their viability and lack of $A \beta$ generation. ${ }^{115}$ Recently developed BACE1 overexpressing and BACE1 knockout mice are also viable and fertile and neither develop overt amyloid pathology. ${ }^{116}$ BACE1 knockout mice crossed with APP overexpressing mice do not form plaques, confirming the necessity of this enzyme in $\mathrm{A} \beta$ production. ${ }^{117}$ Overexpression of both $\mathrm{BACE}$ and $\mathrm{APP}_{\text {Swe }}$ in mice accelerates amyloid deposition, ${ }^{118}$ further supporting the importance of this enzyme in $\mathrm{A} \beta$ production.

To summarize interactions with APP in transgenic mouse models, overexpressing mutant presenilins accelerates amyloid deposition, crossing with ApoE knockout mice decreases amyloid deposition, ApoE4 expression increases plaque deposition, decreasing LRP expression increases amyloid deposition, BACE1 knockouts abolish $\mathrm{A} \beta$ production, and BACE1 overexpression accelerates $\mathrm{A} \beta$ deposition (Table 2). In the next section, we will explore tau overexpressing mouse models and their interactions with amyloid deposition. 
TABLE 2. Modifiers of Amyloid Pathology in APP-Overexpressing Mice

\begin{tabular}{llc}
\hline Model & \multicolumn{1}{c}{ Effect on Amyloid Pathology } & References \\
\hline Presenilin transgenic & Accelerates amyloid deposition & $82,83,85,88$ \\
ApoE knockout & Decrease amyloid deposition & 106 \\
ApoE transgenic (on ApoE null background) & Enhances amyloid deposition & 109 \\
LRP reduction & Increases amyloid deposition & 113 \\
BACE1 knockout & Abolishes A $\beta$ production (prevents amyloid pathology) & 117 \\
BACE1 transgenic & Accelerates amyloid deposition & 118 \\
TGF- $\beta 1$ & Increases vascular deposition, decreases plaque deposition & $190-192$
\end{tabular}

\section{TAU TRANSGENIC MOUSE MODELS}

To model the NFT pathology in AD and other tauopathies, tau transgenic mice have been developed. The tau protein binds microtubules, polymerizes actin, and participates in intracellular trafficking. ${ }^{119,120}$ In healthy adult brain, tau is located in axons, but in AD and other tauopathies, it is hyperphosphorylated and is found in cell bodies and dendrites as well as axons. Pathogenic mutations in the tau gene that cause frontotemporal dementia and parkinsonism linked to chromosome 17 (FTDP-17) either reduce the ability of tau to bind to microtubules or alter the splicing of exon 10 resulting in increased 4 repeat tau isoforms (containing 4 microtubule-binding domains). ${ }^{121}$

The first transgenic tau models expressing wild-type human tau were generated in 1995 before pathogenic tau mutations had been identified. Overexpressing the longest isoform of human tau (4 repeat) under the human Thy 1 promoter (ALZ7 line) resulted in hyperphosphorylation of tau and somatodendritic localization; however, these mice did not form NFT. ${ }^{122}$ Higher expression levels of the same construct with the mouse Thy 1.2 promoter (ALZ17 line) also failed to develop NFT or cell loss despite extensive phosphorylation of tau and axonal pathology in central and spinal cord neurons ${ }^{123-125}$ similar to that seen in spinal cord motor neurons of people with amyotrophic lateral sclerosis. ${ }^{126}$ Consistent with the observation of axonopathy, behavioral studies of these mice showed muscle weakness. ${ }^{124}$ These two models showed that overexpression of human wild-type 4 repeat tau is insufficient to induce NFT formation, but the somatodendritic localization of tau in neurons does resemble the "pre-tangle" state observed in AD.

Overexpressing wild-type human 3 repeat tau under the mouse prion promoter also resulted in hyperphosphorylation of tau and axonopathy in the spinal cord. ${ }^{127}$ These mice also develop rare NFT in the hippocampus, amygdala, and entorhinal cortex, albeit at very old ages (18-20 months). Using a P1-derived artificial chromosome (PAC) transgene containing the complete human tau gene, Duff et al. ${ }^{128}$ created mice that express all six human tau isoforms. Human tau expression is found in neuronal processes and synaptic terminals, but there is no evidence of tau hyperphosphorylation or tangle formation in these mice. Interestingly, crossing these mice with tau null mice led to a more robust phenotype with neurofibrillary lesions and cell loss. ${ }^{129}$

Because overexpression of wild-type human tau isoforms in mice replicated only very limited aspects of tau pathology in $\mathrm{AD}$ and other tauopathies, many groups turned to the newly discovered pathogenic tau mutations for use in animal models. Expression of the FTDP-17associated mutation P301L in the shortest four repeat tau isoform under the mouse prion promoter (JNPL3 line) caused NFT formation in the spinal cord, brainstem, cerebellum, diencephalon, and basal telencephalon. ${ }^{130}$ These mice also developed motor deficits and cell loss in the spinal cord. ${ }^{130}$ A recent study also showed a correlation between the number of NFT and decline in performance on the Morris water maze in JNPL3 mice, indicating a detrimental effect of NFT on memory. ${ }^{131}$ Another P301L tau transgenic mouse expressing the longest four repeat isoform under the mouse Thy-1 promoter also developed NFT in the brainstem, spinal cord, and cortex by 8 months of age. ${ }^{132}$ Astrocytosis accompanied tau pathology in these mice, and terminal transferase-mediated $2^{\prime}$-deoxyuridine $5{ }^{\prime}$-triphosphate nick end labeling (TUNEL) staining showed neuronal apoptosis. ${ }^{132}$ A new P301L tau transgenic mouse line has recently been developed, which demonstrates progressive neurofibrillary pathology and neuronal loss. ${ }^{133}$ This model is particularly interesting because the tau transgene is controlled by a tetracycline-regulatable operon such that tau production can be turned off by adding doxycycline to the food.

The P301S FTDP-17-associated mutation has also been used to make mouse models. P301S mutant tau expressed under the mouse Thy 1.2 promoter caused human tau expression in the spinal cord, brainstem, hippocampus, and neocortex. ${ }^{134}$ Expression was particularly high in the spinal cord, where half of the motor neurons also died. Tau was phosphorylated but no neurofibrillary pathology was observed in these mice. ${ }^{134}$

\section{Tau-interacting proteins}

With the development of P301L mouse models that develop neurofibrillary pathology, intense interest be- 
came focused on how $\mathrm{A} \beta$ would affect NFT formation. Injection of synthetic $\mathrm{A} \beta_{42}$ into somatosensory cortex and contralateral hippocampus of P301L mice caused a fivefold increase in NFT numbers in the amygdala, which receives projections from both cortex and hippocampus. ${ }^{135}$ Injecting $\mathrm{A} \beta$ into wild-type tau expressing mice or nontransgenic mice did not result in tangle formation. ${ }^{135}$ Crossing Tg2576 mice that produce $\mathrm{A} \beta$ with JNPL3 tau mice (P301L mutation) resulted in a doubletransgenic strain that developed both plaques and tangles. Whereas the presence of tau did not affect amyloid pathology, the presence of amyloid greatly enhanced NFT formation in the amygdala, entorhinal cortex, and olfactory bulb of double transgenic mice. ${ }^{136}$ This result is very interesting because it implicates disrupted amyloid processing in tangle formation and the amyloid-induced NFT formation occurred in brain areas vulnerable in AD.

Oddo et al. ${ }^{137}$ recently developed another transgenic model combining amyloid and tau pathology. Their 3xTg-AD mice harbor mutations of APP (Swedish), PS1 (M146V), and tau (P301L). These mice develop plaques first in the neocortex (around 3 months of age) that spread to the hippocampus by 6 months. Tangles develop after amyloid pathology. They appear first in the hippocampus (at 12 months), then spread to the cortex. ${ }^{138}$ This regional and temporal development of pathology closely mimics the development of pathology in $\mathrm{AD}-$ making this an excellent disease model. The appearance of amyloid pathology before tau pathology despite similar levels of expression also supports the amyloid cascade hypothesis of AD pathogenesis. Moreover, treatment of the amyloid pathology also led to a partial resolution of tau abnormalities as will be discussed later. $3 \times T g$ mice also exhibit synaptic dysfunction, including LTP deficits that surprisingly precede plaque and tangle formation. ${ }^{137}$

The association of apolipoprotein E $\epsilon 4$ allele with increasing risk of $\mathrm{AD}$ is usually thought to be based on the effects of ApoE on amyloid pathology. Recent evidence from transgenic mouse models indicate that ApoE may also affect tau phosphorylation and accumulation. Overexpression of ApoE4 and to a lesser extent ApoE3 under a neuron specific promoter (on an ApoE knockout background) induces aggregation of phosphorylated tau in brain areas vulnerable in $\mathrm{AD}{ }^{139}$ When ApoE4 and ApoE3 were expressed under a glial promoter (GFAP), there was no accumulation of phosphorylated tau, indicating a role for neuron-specific ApoE4 in neurofibrillary tangle formation. ${ }^{139}$ This result is, however, puzzling because ApoE is primarily synthesized by glia, and neuronal expression of ApoE remains controversial.

Because NFT invariably contain hyperphosphorylated tau with conformational alterations, several groups have generated mouse models that up or down-regulate tau phosphorylation or change its conformation. One poten- tial tau kinase, GSK-3 $\beta$, has been overexpressed in a tetracycline operon-regulated system. Double-transgenic mice that express CamKII $\alpha$-tTA/tetop-GSK- $3 \beta$ express GSK- $3 \beta$ only in the absence of doxycycline (a tetracycline analog). When doxycycline is added to the food or water of the mice, the GSK-3 $\beta$ gene is turned off by inactivating the tetracycline transactivator protein expressed using the CamKII $\alpha$ promoter. GSK- $3 \beta$ overexpression caused hyperphosphorylation of tau, development of pre-tangle-like structures, astrogliosis, and increased TUNEL staining indicating apoptosis; however, no NFT were present in these mice. ${ }^{140}$ Another potential tau kinase, cdk5, has also been investigated in transgenic animal models by creating mice that overexpress $\mathrm{p} 25$, an activator of cdk5. p25 transgenic mice have increased cdk5 activity, hyperphosphorylated tau in the brain, cytoskeletal disruptions, and behavioral abnormalities. ${ }^{141}$ Furthermore, crossing p25 transgenic mice with P301L tau transgenic mice results in increased NFT formation. ${ }^{142}$ Of course, proteins involved in dephosphorylation of tau are also of interest. Protein phosphatase 2A (PP2A) is implicated in tau dephosphorylation in $\mathrm{AD}$, and reducing PP2A in transgenic mice increases tau phosphorylation. ${ }^{143}$ The prolyl isomerase Pin1 has also been investigated in mouse models because it can induce a conformational change in tau that restores tau function and promotes dephosphorylation by phosphatases, including PP2A. ${ }^{144}$ Pin1 knockout mice develop progressive motor deficits and NFT, ${ }^{145}$ demonstrating that endogenous mouse tau is capable of forming filaments.

In summary, tau transgenic models can recapitulate some of the neurofibrillary pathology of Alzheimer's disease, including age-dependent tangle formation with regional specificity. In combination with APP overexpressing mice, these animals provide excellent tools for studying disease mechanisms and testing treatments. However, rodent models are relatively slow to develop lesions and often they are only available in small numbers. In the next section, we briefly review nonrodent transgenic models of $\mathrm{AD}$ that circumvent these issues.

\section{NONRODENT TRANSGENIC MODELS}

Many groups use nonmammalian experimental model species to study the biology of AD (Table 3). Although they are not very accurate reproductions of AD pathology, these models offer tools to study the biology of cascades involved in the disease quickly and at low cost. The most commonly used invertebrate model organisms in the study of neurodegeneration are the fruit fly Drosophila melanogaster and the nematode Ceanorhabditis elegans. In 1989, Rosen and colleagues ${ }^{146}$ reported a homolog of APP in Drosophila named amyloid precursor protein-like protein (APPL). C. elegans also expresses an APP homolog: the amyloid precursor-like 
TABLE 3. Nonrodent Models of $A D$

\begin{tabular}{|c|c|c|c|}
\hline Species & Gene Overexpressed & Effect & References \\
\hline \multirow[t]{4}{*}{ Drosophila } & APPL or huAPP & Axonal transport phenotype & 148 \\
\hline & huAPP & Neuronal apoptosis & 148 \\
\hline & huTau & Neurodegeneration & 159 \\
\hline & huTau and GSK-3 homolog & NFT and neurodegeneration & 160 \\
\hline \multirow[t]{2}{*}{ C. elegans } & $\mathrm{A} \beta$ (in bodywall) & Paralysis & 149,150 \\
\hline & huTau & Neurodegeneration, synaptic and behavioral abnormalities & 162 \\
\hline P. marinus & huTau & Neurodegeneration & 165 \\
\hline
\end{tabular}

$\mathrm{hu}=$ human.

protein 1 (APL-1). ${ }^{147}$ Both of these homologs are similar to APP throughout their length, but the A $\beta$ regions lacks similarity to human APP. In Drosophila, overexpression of APPL or several human APP constructs (with and without mutations) causes an axonal transport phenotype similar to that seen in kinesin and dynein mutants, ${ }^{148}$ implicating APP in axonal transport. Furthermore, this study showed that expressing human constructs induced neuronal apoptosis dependent upon the presence of the C-terminal region (putative kinesin binding site) and the $\mathrm{A} \beta$ region. Studies of APP in $C$. elegans show that expression of $\mathrm{A} \beta$ in the bodywall muscle induces progressive paralysis and shortens life span. ${ }^{149,150}$ Enhancing heat shock protein 70 (HSP70) activity by knocking down a negative HSP70 regulator suppresses this $A \beta$ mediated paralysis, ${ }^{151}$ implicating the chaperone effects of HSP70 in clearance of $\mathrm{A} \beta$.

Both Drosophila and C. elegans express presenilin homologs that cleave Notch family proteins, ${ }^{152-155}$ and invertebrate studies have contributed to the identification of $\gamma$-secretase complex components nicastrin, APH1, and PEN1. ${ }^{156-158}$ Tau has also been studied in both Drosophila and C. elegans. Overexpression of wild-type and FTDP-17-associated mutant tau in Drosophila results in adult-onset neurodegeneration without neurofibrillary tangle formation. ${ }^{159}$ Overexpression of tau with a GSK- $3 \beta$ homolog (involved in tau phosphorylation) induced neurofibrillary pathology, albeit with a different conformation than that seen in human tangles. ${ }^{160}$ Coexpression of tau and APPL in Drosophila leads to neuronal dysfunction and disrupted axonal transport. ${ }^{161}$ In $C$. elegans, tau overexpression leads to pathological changes and behavioral and synaptic abnormalities. These effects are more pronounced with expression of mutant tau than wild-type tau. ${ }^{162}$

One further invertebrate used to study Alzheimer's disease is the sea lamprey Petromyzon marinus. This fish has a CNS characterized by six giant neurons in the hindbrain, which have been extensively studied. ${ }^{163} \mathrm{Mi}-$ croinjections of self-replicating mRNA to induce chronic tau overexpression leads to degeneration of these neurons starting with their distal dendrites. ${ }^{164}$ Furthermore, a low molecular weight, lipid-soluble compound has been identified that retards the progression of tau-induced degeneration. $^{165}$

Invertebrate models have very different brain anatomy from mammals, but their low cost, small size, short life span, and highly characterized genetics make them well suited for drug screening and determination of cell biology involved in $\mathrm{AD}$ pathogenesis.

\section{TREATMENTS ARISING FROM ANIMAL STUDIES}

The recent boon in transgenic animal models of $\mathrm{AD}$ has led to very promising targets for therapeutics, some of which have progressed to clinical trials. In the search for treatments, several approaches present themselves including reducing $\mathrm{A} \beta$ production and fibrillogenesis, and clearance of $\mathrm{A} \beta$ plaques and NFT.

Inhibiting $\gamma$-secretase should reduce $\mathrm{A} \beta$ production, and indeed treatment of PDAPP and $\mathrm{Tg} 2576$ mice with a $\gamma$-secretase inhibitor decreases $A \beta$ levels. ${ }^{166,167}$ One major concern of using $\gamma$-secretase inhibitors as a therapy is the effect they would have on substrates other than APP. For example, $\gamma$-secretase regulates Notch signaling, an essential pathway in embryonic development. ${ }^{168}$ As discussed previously, presenilin 1 knockout mice die before birth, confirming the importance of this protein in development. Chronic treatment with $\gamma$-secretase inhibitors in TgCRNR8 mice produced Notch-related side effects in the gastrointestinal tract and spleen as well as reducing $\mathrm{A} \beta$ levels. ${ }^{169}$ An interesting method of targeting PS1 action to produce less of the fibrillogenic $\mathrm{A} \beta_{42}$ peptide was revealed by epidemiological studies showing a protective effect of some nonsteroidal anti-inflammatories (NSAIDS) in AD. Certain NSAIDs modulate $\gamma$-secretase cleavage in 11-month-old $\mathrm{Tg} 2576$ mice wherein treatment with ibuprofen reduced $\mathrm{A} \beta_{42}$ levels and cortical plaque burden. ${ }^{170}$ Recent data have shown that in PS1 overexpressing mice, ibuprofen treatment similarly reduces the $\mathrm{A} \beta_{42} / \mathrm{A} \beta_{40}$ ratio. ${ }^{171,172}$ Interestingly, Lleo et al. ${ }^{171}$ also provided data showing that the action of NSAIDs on $\mathrm{A} \beta_{42}$ levels may be due to a direct effect on the conformation of presenilin which favors production of shorter forms of $\mathrm{A} \beta$. 
Because of the difficulties surrounding $\gamma$-secretase inhibition, $\beta$-secretase has become a target of interest, especially because BACE1 knockout mice are viable and when crossed with APP, they do not form plaques. ${ }^{114}$ However, finding BACE inhibitors is proving difficult although work continues in this direction. ${ }^{173}$

Several advances have been made in preventing $\mathrm{A} \beta$ fibrillization using animal models. Metal ions have been implicated as $\mathrm{A} \beta$-interacting molecules, and there has been interest in using metal chelating substances as a treatment for AD. ${ }^{174}$ Treatment of Tg2576 mice with the antibiotic clioquinol that chelates zinc and copper ions resulted in decreased $A \beta$ deposition. ${ }^{175}$ Similarly, crossing APP mice with ZnT3 zinc transporter knockout mice reduced $\mathrm{A} \beta$ deposition. ${ }^{176} \mathrm{~A}$ small pilot clinical trial of clioquinol indicated no overall cognitive benefit of treatement although post hoc analysis revealed an improvement with treatment in a subset of more severely affected patients. ${ }^{177}$

By far, the most interesting treatment resulting from animal models of AD arose from the landmark immunization studies of Schenk et al. ${ }^{178}$ They found that immunization of PDAPP mice with fibrillar $\mathrm{A} \beta_{42}$ prevented the development of amyloid pathology when administered to young mice and reduced the extent of pathology when given to older mice. Subsequent experiments confirmed the neuropathological benefits of both active and passive immunization and furthermore showed that immunization ameliorated memory deficits in several mouse models of AD. ${ }^{179-182}$ Plaque-induced alterations in the trajectory of neurites ${ }^{183}$ are also ameliorated with immunotherapy in APP mice. ${ }^{184}$ Interestingly, Oddo et al. ${ }^{185}$ recently reported that immunotherapy with $\mathrm{A} \beta$ antibodies in 3xTg mice that have both plaques and tangles led not only to plaque clearance but also to a reduction in tau burden by clearing early tau pathology. Plaques cleared first, followed by nonphosphorylated somatodendritic tau accumulations. Furthermore, $\mathrm{A} \beta$ deposits reemerged before the reappearance of tau pathology strongly supporting a direct relationship between amyloid and tau pathology. ${ }^{185}$ This work adds to the body of evidence linking altered amyloid processing with induction of tau pathology.

The promising early immunotherapy data from mice led to a rapid transition to clinical trials. A large-scale placebo-controlled trial of immunotherapy with $\mathrm{A} \beta_{42}$ was prematurely terminated after some of the participants developed meningoencephalitis- $6 \%$ of the patients receiving immunotherapy developed this serious side effect. ${ }^{186}$ Autopsy data from two participants revealed the encouraging finding of reduced $\mathrm{A} \beta$ plaque burden in some areas of cortex with associated reductions in astrogliosis and dystrophic neurites. ${ }^{187,188}$ Furthermore, a small cohort of patients has been tested for improvements in cognitive function and the data indicate an improvement on Mini-Mental State Examination and the disability assessment for dementia rating scale specifically in those patients who developed antibodies to $\mathrm{A} \beta .^{189}$ Although this trial had to be halted due to inflammatory side effects, the promising, if incomplete, follow-up data indicate that safer methods of immunotherapy are worth pursuing.

In conclusion, by taking advantage of results of genetic studies of familial AD, transgenic animal models of Alzheimer's disease have been developed in species ranging from worms to rats. Although none completely recapitulate the disease process, they have proven to be robust models for neuropathological changes and have already allowed the study of genetic interactions in great detail. In aggregate, transgenic models have thus already contributed a great deal to our understanding of the basic biology and pathogenesis of AD as well as providing test systems for drugs.

Acknowledgments: This work was supported by National Institutes of Health Grants NIA-5 T32 AG00277 and AG08487, and a Pioneer award from the Alzheimer Association.

\section{REFERENCES}

1. Hebert LE, Scherr PA, Bienias JL, Bennett DA, Evans DA. Alzheimer disease in the US population: prevalence estimates using the 2000 census. Arch Neurol 60:1119-1122, 2003.

2. Citron M. Strategies for disease modification in Alzheimer's disease. Nat Rev Neurosci 5:677-685, 2004.

3. Faber-Langendoen K, Morris JC, Knesevich JW, LaBarge E, Miller JP, Berg L. Aphasia in senile dementia of the Alzheimer type. Ann Neurol 23:365-370, 1988.

4. Rubin EH, Morris JC, Storandt M, Berg L. Behavioral changes in patients with mild senile dementia of the Alzheimer's type. Psychiatry Res 21:55-62, 1987.

5. Swearer JM, Drachman DA, O'Donnell BF, Mitchell AL. Troublesome and disruptive behaviors in dementia. Relationships to diagnosis and disease severity. J Am Geriatr Soc 36:784-790, 1988.

6. Morris JC, Drazner M, Fulling K, Grant EA, Goldring J. Clinical and pathological aspects of parkinsonism in Alzheimer's disease. A role for extranigral factors? Arch Neurol 46:651-657, 1989.

7. Romanelli MF, Morris JC, Ashkin K, Coben LA. Advanced Alzheimer's disease is a risk factor for late-onset seizures. Arch Neurol 47:847-850, 1990.

8. Alzheimer A. Ubereine eigenartige Erkrankung der Hirnrinde. [A peculiar disease of the cerebral cortex.] Allg Z Psychiatr-Gerichtl Med 64:146-148, 1907.

9. Divry P, Florkin M. Sur les proprietés optiques de l'amaloide. [On the optical properties of amyloid.] C R Soc Biol 97:18081810, 1927.

10. Glenner GG, Wong CW. Alzheimer's disease and Down's syndrome: sharing of a unique cerebrovascular amyloid fibril protein. Biochem Biophys Res Commun 122:1131-1135, 1984.

11. Kang J, Lemaire HG, Unterbeck A, Salbaum JM, Masters CL, Grzeschik KH, et al. The precursor of Alzheimer's disease amyloid A4 protein resembles a cell-surface receptor. Nature 325: 733-736, 1987.

12. Yamaguchi H, Hirai S, Morimatsu M, Shoji M, Ihara Y. A variety of cerebral amyloid deposits in the brains of the Alzheimer-type dementia demonstrated by $\beta$ protein immunostaining. Acta Neuropathol (Berl) 76:541-549, 1988. 
13. Yamaguchi H, Hirai S, Morimatsu M, Shoji M, Harigaya Y. Diffuse type of senile plaques in the brains of Alzheimer-type dementia. Acta Neuropathol (Berl) 77:113-119, 1988.

14. Dickson TC, Vickers JC. The morphological phenotype of $\beta$-amyloid plaques and associated neuritic changes in Alzheimer's disease. Neuroscience 105:99-107, 2001.

15. Hyman BT, Van Hoesen GW, Kromer LJ, Damasio AR. Perforant pathway changes and the memory impairment of Alzheimer's disease. Ann Neurol 20:472-481, 1986.

16. Rogers J, Morrison JH. Quantitative morphology and regional and laminar distributions of senile plaques in Alzheimer's disease. J Neurosci 5:2801-2808, 1985.

17. Pearson RC, Esiri MM, Hiorns RW, Wilcock GK, Powell TP. Anatomical correlates of the distribution of the pathological changes in the neocortex in Alzheimer disease. Proc Natl Acad Sci USA 82:4531-4534, 1985.

18. Duyckaerts C, Hauw JJ, Bastenaire F, Piette F, Poulain C, Rainsard $\mathrm{V}$, et al. Laminar distribution of neocortical senile plaques in senile dementia of the Alzheimer type. Acta Neuropathol (Berl) 70:249-256, 1986.

19. Ingelsson $\mathrm{M}$, Fukumoto $\mathrm{H}$, Newell KL, Growdon $\mathrm{JH}$, HedleyWhyte ET, Frosch MP, et al. Early A $\beta$ accumulation and progressive synaptic loss, gliosis, and tangle formation in AD brain. Neurology 62:925-931, 2004.

20. Braak H, Braak E. Frequency of stages of Alzheimer-related lesions in different age categories. Neurobiol Aging 18:351-357, 1997.

21. Urbanc B, Cruz L, Buldyrev SV, Havlin S, Irizarry MC, Stanley $\mathrm{HE}$, et al. Dynamics of plaque formation in Alzheimer's disease. Biophys J 76:1330-1334, 1999.

22. Cruz L, Urbanc B, Buldyrev SV, Christie R, Gomez-Isla T, Havlin S, et al. Aggregation and disaggregation of senile plaques in Alzheimer disease. Proc Natl Acad Sci USA 94:7612-7616, 1997.

23. Kidd M. Paired helical filaments in electron microscopy in Alzheimer's disease. Nature 197:192-193, 1963.

24. Brion JP, Couck AM, Passareiro E, Flament-Durand J. Neurofibrillary tangles of Alzheimer's disease: an immunohistochemical study. J Submicrosc Cytol 17:89-96, 1985.

25. Hyman BT, Van Horsen GW, Damasio AR, Barnes CL. Alzheimer's disease: cell-specific pathology isolates the hippocampal formation. Science 225:1168-1170, 1984.

26. Hof PR, Morrison JH. The cellular basis of cortical disconnection in Alzheimer disease and related dementing conditions. In: Alzheimer disease (Terry R, Katzman R, Bick KL, Sisoda SS, eds), pp 207-232. Philadelphia: Lippincott Williams \& Wilkins, 1999.

27. Klucken J, McLean PJ, Gomez-Tortosa E, Ingelsson M, Hyman BT. Neuritic alterations and neural system dysfunction in Alzheimer's disease and dementia with Lewy bodies. Neurochem Res 28:1683-1691, 2003.

28. Arriagada PV, Marzloff K, Hyman BT. Distribution of Alzheimer-type pathologic changes in nondemented elderly individuals matches the pattern in Alzheimer's disease. Neurology 42:16811688, 1992.

29. Wilcock GK, Esiri MM. Plaques, tangles and dementia. A quantitative study. J Neurol Sci 56:343-356, 1982.

30. Giannakopoulos P, Herrmann FR, Bussiere T, Bouras C, Kovari E, Perl DP, et al. Tangle and neuron numbers, but not amyloid load, predict cognitive status in Alzheimer's disease. Neurology 60:1495-1500, 2003

31. Morrison JH, Hof PR. Life and death of neurons in the aging brain. Science 278:412-419, 1997.

32. Bussiere T, Giannakopoulos P, Bouras C, Perl DP, Morrison JH, Hof PR. Progressive degeneration of nonphosphorylated neurofilament protein-enriched pyramidal neurons predicts cognitive impairment in Alzheimer's disease: stereologic analysis of prefrontal cortex area 9. J Comp Neurol 463:281-302, 2003.

33. Squire LR, Zola-Morgan S. The medial temporal lobe memory system. Science 253:1380-1386, 1991.

34. Gomez-Isla T, Hollister R, West H, Mui S, Growdon JH, Petersen $\mathrm{RC}$, et al. Neuronal loss correlates with but exceeds neurofibrillary tangles in Alzheimer's disease. Ann Neurol 41:17-24, 1997.
35. West MJ, Coleman PD, Flood DG, Troncoso JC. Differences in the pattern of hippocampal neuronal loss in normal ageing and Alzheimer's disease. Lancet 344:769-772, 1994.

36. Spires TL, Hyman BT. Neuronal structure is altered by amyloid plaques. Rev Neurosci, 15:267-278, 2004.

37. Terry RD, Masliah E, Salmon DP, Butters N, DeTeresa R, Hill R, et al. Physical basis of cognitive alterations in Alzheimer's disease: synapse loss is the major correlate of cognitive impairment. Ann Neurol 30:572-580, 1991.

38. Masliah E, Hansen L, Albright T, Mallory M, Terry RD. Immunoelectron microscopic study of synaptic pathology in Alzheimer's disease. Acta Neuropathol (Berl) 81:428-433, 1991.

39. DeKosky ST, Scheff SW. Synapse loss in frontal cortex biopsies in Alzheimer's disease: correlation with cognitive severity. Ann Neurol 27:457-464, 1990.

40. Hardy J, Selkoe DJ. The amyloid hypothesis of Alzheimer's disease: progress and problems on the road to therapeutics. Science 297:353-356, 2002.

41. Tanzi RE, Bertram L. New frontiers in Alzheimer's disease genetics. Neuron 32:181-184, 2001.

42. St George-Hyslop PH. Genetic factors in the genesis of Alzheimer's disease. Ann NY Acad Sci 924:1-7, 2000.

43. Wisniewski KE, Dalton AJ, McLachlan C, Wen GY, Wisniewski HM. Alzheimer's disease in Down's syndrome: clinicopathologic studies. Neurology 35:957-961, 1985.

44. Goate AM, Haynes AR, Owen MJ, Farrall M, James LA, Lai LY, et al. Predisposing locus for Alzheimer's disease on chromosome 21. Lancet 1:352-355, 1989.

45. Tanzi RE, Gusella JF, Watkins PC, Bruns GA, St George-Hyslop $\mathrm{P}$, Van Keuren ML, et al. Amyloid $\beta$ protein gene: cDNA, mRNA distribution, and genetic linkage near the Alzheimer locus. Science 235:880-884, 1987.

46. Goate A, Chartier-Harlin MC, Mullan M, Brown J, Crawford F, Fidani L, et al. Segregation of a missense mutation in the amyloid precursor protein gene with familial Alzheimer's disease. Nature 349:704-706, 1991.

47. Naruse S, Igarashi S, Kobayashi H, Aoki K, Inuzuka T, Kaneko $\mathrm{K}$, et al. Mis-sense mutation Val-Ile in exon 17 of amyloid precursor protein gene in Japanese familial Alzheimer's disease. Lancet 337:978-979, 1991.

48. Alzheimer's Disease Collaborative Research Group. The structure of the presenilin 1 (S182) gene and identification of six novel mutations in early onset AD families. Nat Genet 11:219-222, 1995.

49. Sherrington R, Rogaev EI, Liang Y, Rogaeva EA, Levesque G, Ikeda $\mathrm{M}$, et al. Cloning of a gene bearing missense mutations in early-onset familial Alzheimer's disease. Nature 375:754-760, 1995.

50. St George-Hyslop P, Haines J, Rogaev E, Mortilla M, Vaula G, Pericak-Vance M, et al. Genetic evidence for a novel familial Alzheimer's disease locus on chromosome 14. Nat Genet 2:330334, 1992.

51. Levy-Lahad E, Wijsman EM, Nemens E, Anderson L, Goddard KA, Weber JL, et al. A familial Alzheimer's disease locus on chromosome 1. Science 269:970-973, 1995.

52. Rogaev EI, Sherrington R, Rogaeva EA, Levesque G, Ikeda M, Liang Y, et al. Familial Alzheimer's disease in kindreds with missense mutations in a gene on chromosome 1 related to the Alzheimer's disease type 3 gene. Nature 376:775-778, 1995.

53. De Strooper B. Aph-1, Pen-2, and Nicastrin with Presenilin generate an active $\gamma$-secretase complex. Neuron 38:9-12, 2003.

54. Selkoe DJ. Biology of $\beta$-amyloid precursos protein and the mechanism of Alzheimer disease. In: Alzheimer disease (Terry RD, Katzman R, Bick KL, Sisoda SS, eds), pp 293-310. Philadelphia: Lippincott Williams \& Wilkins, 1999.

55. Saunders AM, Strittmatter WJ, Schmechel D, George-Hyslop PH, Pericak-Vance MA, Joo SH, et al. Association of apolipoprotein E allele epsilon 4 with late-onset familial and sporadic Alzheimer's disease. Neurology 43:1467-1472, 1993.

56. Corder EH, Saunders AM, Strittmatter WJ, Schmechel DE, Gaskell PC, Small GW, et al. Gene dose of apolipoprotein E type 4 allele and the risk of Alzheimer's disease in late onset families. Science 261:921-923, 1993. 
57. Corder EH, Saunders AM, Risch NJ, Strittmatter WJ, Schmechel DE, Gaskell PC Jr, et al. Protective effect of apolipoprotein E type 2 allele for late onset Alzheimer disease. Nat Genet 7:180184, 1994.

58. Strittmatter WJ, Saunders AM, Schmechel D, Pericak-Vance M, Enghild J, Salvesen GS, et al. Apolipoprotein E: high-avidity binding to $\beta$-amyloid and increased frequency of type 4 allele in late-onset familial Alzheimer disease. Proc Natl Acad Sci USA 90:1977-1981, 1993.

59. Wisniewski T, Frangione B. Apolipoprotein E: a pathological chaperone protein in patients with cerebral and systemic amyloid. Neurosci Lett 135:235-238, 1992.

60. Foster NL, Wilhelmsen K, Sima AA, Jones MZ, D'Amato CJ, Gilman S. Frontotemporal dementia and parkinsonism linked to chromosome 17: a consensus conference. Conference Participants. Ann Neurol 41:706-715, 1997.

61. Kawabata S, Higgins GA, Gordon JW. Amyloid plaques, neurofibrillary tangles and neuronal loss in brains of transgenic mice overexpressing a C-terminal fragment of human amyloid precursor protein. Nature 354:476-478, 1991.

62. Wirak DO, Bayney R, Ramabhadran TV, Fracasso RP, Hart JT, Hauer PE, et al. Deposits of amyloid $\beta$ protein in the central nervous system of transgenic mice. Science 253:323-325, 1991.

63. Games D, Adams D, Alessandrini R, Barbour R, Berthelette P, Blackwell C, et al. Alzheimer-type neuropathology in transgenic mice overexpressing V717F $\beta$-amyloid precursor protein. Nature 373:523-527, 1995.

64. Quon D, Wang Y, Catalano R, Scardina JM, Murakami K, Cordell B. Formation of $\beta$-amyloid protein deposits in brains of transgenic mice. Nature 352:239-241, 1991.

65. Mucke L, Masliah E, Johnson WB, Ruppe MD, Alford M, Rockenstein EM, et al. Synaptotrophic effects of human amyloid $\beta$ protein precursors in the cortex of transgenic mice. Brain Res 666:151-167, 1994.

66. Higgins LS, Holtzman DM, Rabin J, Mobley WC, Cordell B. Transgenic mouse brain histopathology resembles early Alzheimer's disease. Ann Neurol 35:598-607, 1994.

67. Masliah E, Sisk A, Mallory M, Mucke L, Schenk D, Games D. Comparison of neurodegenerative pathology in transgenic mice overexpressing V717F $\beta$-amyloid precursor protein and Alzheimer's disease. J Neurosci 16:5795-5811, 1996.

68. Irizarry MC, Soriano F, McNamara M, Page KJ, Schenk D, Games $\mathrm{D}$, et al. A $\beta$ deposition is associated with neuropil changes, but not with overt neuronal loss in the human amyloid precursor protein V717F (PDAPP) transgenic mouse. J Neurosci 17:7053-7059, 1997.

69. Chen G, Chen KS, Knox J, Inglis J, Bernard A, Martin SJ, et al. A learning deficit related to age and $\beta$-amyloid plaques in a mouse model of Alzheimer's disease. Nature 408:975-979, 2000.

70. Masliah E, Sisk A, Mallory M, Games D. Neurofibrillary pathology in transgenic mice overexpressing V717F $\beta$-amyloid precursor protein. J Neuropathol Exp Neurol 60:357-368, 2001.

71. Urbanc B, Cruz L, Le R, Sanders J, Ashe KH, Duff K, et al. Neurotoxic effects of thioflavin S-positive amyloid deposits in transgenic mice and Alzheimer's disease. Proc Natl Acad Sci USA 99:13990-13995, 2002.

72. Hsiao K, Chapman P, Nilsen S, Eckman C, Harigaya Y, Younkin $\mathrm{S}$, et al. Correlative memory deficits, $\mathrm{A} \beta$ elevation, and amyloid plaques in transgenic mice. Science 274:99-102, 1996.

73. Chapman PF, White GL, Jones MW, Cooper-Blacketer D, Marshall VJ, Irizarry M, et al. Impaired synaptic plasticity and learning in aged amyloid precursor protein transgenic mice. Nat Neurosci 2:271-276, 1999.

74. Stern EA, Bacskai BJ, Hickey GA, Attenello FJ, Lombardo JA, Hyman BT. Cortical synaptic integration in vivo is disrupted by amyloid- $\beta$ plaques. J Neurosci 24:4535-4540, 2004.

75. Irizarry MC, McNamara M, Fedorchak K, Hsiao K, Hyman BT. APPSw transgenic mice develop age-related A $\beta$ deposits and neuropil abnormalities, but no neuronal loss in CA1. J Neuropathol Exp Neurol 56:965-973, 1997.

76. Lanz TA, Carter DB, Merchant KM. Dendritic spine loss in the hippocampus of young PDAPP and Tg2576 mice and its prevention by the ApoE2 genotype. Neurobiol Dis 13:246-253, 2003.
77. Sturchler-Pierrat C, Abramowski D, Duke M, Wiederhold KH, Mistl C, Rothacher S, et al. Two amyloid precursor protein transgenic mouse models with Alzheimer disease-like pathology. Proc Natl Acad Sci USA 94:13287-13292, 1997.

78. Van Dam D, D'Hooge R, Staufenbiel M, Van Ginneken C, Van Meir F, De Deyn PP. Age-dependent cognitive decline in the APP23 model precedes amyloid deposition. Eur J Neurosci 17: 388-396, 2003.

79. Kelly PH, Bondolfi L, Hunziker D, Schlecht HP, Carver K, Maguire E, et al. Progressive age-related impairment of cognitive behavior in APP23 transgenic mice. Neurobiol Aging 24:365378, 2003.

80. Lalonde R, Dumont M, Staufenbiel M, Sturchler-Pierrat C, Strazielle C. Spatial learning, exploration, anxiety, and motor coordination in female APP23 transgenic mice with the Swedish mutation. Brain Res 956:36-44, 2002.

81. Calhoun ME, Wiederhold KH, Abramowski D, Phinney AL, Probst A, Sturchler-Pierrat C, et al. Neuron loss in APP transgenic mice. Nature 395:755-756, 1998.

82. Borchelt DR, Ratovitski T, van Lare J, Lee MK, Gonzales V, Jenkins NA, et al. Accelerated amyloid deposition in the brains of transgenic mice coexpressing mutant presenilin 1 and amyloid precursor proteins. Neuron 19:939-945, 1997.

83. Borchelt DR, Thinakaran G, Eckman CB, Lee MK, Davenport F, Ratovitsky T, et al. Familial Alzheimer's disease-linked presenilin 1 variants elevate $\mathrm{A} \beta 1-42 / 1-40$ ratio in vitro and in vivo. Neuron 17:1005-1013, 1996.

84. Dudal S, Krzywkowski P, Paquette J, Morissette C, Lacombe D, Tremblay $\mathrm{P}$, et al. Inflammation occurs early during the $\mathrm{A} \beta$ deposition process in TgCRND8 mice. Neurobiol Aging 25:861871, 2004.

85. Chishti MA, Yang DS, Janus C, Phinney AL, Horne P, Pearson J, et al. Early-onset amyloid deposition and cognitive deficits in transgenic mice expressing a double mutant form of amyloid precursor protein 695. J Biol Chem 276:21562-21570, 2001.

86. Duff K, Eckman C, Zehr C, Yu X, Prada CM, Perez-tur J, et al. Increased amyloid- $\beta 42(43)$ in brains of mice expressing mutant presenilin 1. Nature 383:710-713, 1996.

87. Herreman A, Hartmann D, Annaert W, Saftig P, Craessaerts K, Serneels L, et al. Presenilin 2 deficiency causes a mild pulmonary phenotype and no changes in amyloid precursor protein processing but enhances the embryonic lethal phenotype of presenilin 1 deficiency. Proc Natl Acad Sci USA 96:11872-11877, 1999.

88. Holcomb L, Gordon MN, McGowan E, Yu X, Benkovic S, Jantzen $\mathrm{P}$, et al. Accelerated Alzheimer-type phenotype in transgenic mice carrying both mutant amyloid precursor protein and presenilin 1 transgenes. Nat Med 4:97-100, 1998.

89. Takeuchi A, Irizarry MC, Duff K, Saido TC, Hsiao Ashe K, Hasegawa M, et al. Age-related amyloid $\beta$ deposition in transgenic mice overexpressing both Alzheimer mutant presenilin 1 and amyloid $\beta$ precursor protein Swedish mutant is not associated with global neuronal loss. Am J Pathol 157:331-339, 2000.

90. Holcomb LA, Gordon MN, Jantzen P, Hsiao K, Duff K, Morgan D. Behavioral changes in transgenic mice expressing both amyloid precursor protein and presenilin-1 mutations: lack of association with amyloid deposits. Behav Genet 29:177-185, 1999.

91. Shen J, Bronson RT, Chen DF, Xia W, Selkoe DJ, Tonegawa S. Skeletal and CNS defects in Presenilin-1-deficient mice. Cell 89:629-639, 1997.

92. Qian S, Jiang P, Guan XM, Singh G, Trumbauer ME, Yu H, et al. Mutant human presenilin 1 protects presenilin 1 null mouse against embryonic lethality and elevates A $\beta 1-42 / 43$ expression. Neuron 20:611-617, 1998.

93. Flood DG, Howland DS, Lin Y-G, Ciallella JR, Trusko SP, Scott RW, Savage MS. A $\beta$ deposition in a transgenic rat model of Alzheimer's disease. Poster 842.22 presented at Society for Neuroscience meeting, New Orleans, LA, 2003.

94. Echeverria V, Ducatenzeiler A, Alhonen L, Janne J, Grant SM, Wandosell F, et al. Rat transgenic models with a phenotype of intracellular $\mathrm{A} \beta$ accumulation in hippocampus and cortex. $J \mathrm{Alz}$ heimers Dis 6:209-219, 2004.

95. Lopez EM, Bell KF, Ribeiro-Da-Silva A, Cuello AC. Early changes in neurons of the hippocampus and neocortex in trans- 
genic rats expressing intracellular human a- $\beta$. J Alzheimers Dis 6:421-431, 2004.

96. Strittmatter WJ, Roses AD. Apolipoprotein E and Alzheimer's disease. Annu Rev Neurosci 19:53-77, 1996.

97. Mahley RW. Apolipoprotein E: cholesterol transport protein with expanding role in cell biology. Science 240:622-630, 1988.

98. Paik YK, Chang DJ, Reardon CA, Davies GE, Mahley RW, Taylor JM. Nucleotide sequence and structure of the human apolipoprotein E gene. Proc Natl Acad Sci USA 82:3445-3449, 1985.

99. Lin-Lee YC, Kao FT, Cheung P, Chan L. Apolipoprotein E gene mapping and expression: localization of the structural gene to human chromosome 19 and expression of ApoE mRNA in lipoprotein- and non-lipoprotein-producing tissues. Biochemistry 24:3751-3756, 1985.

100. Namba Y, Tomonaga M, Kawasaki H, Otomo E, Ikeda K. Apolipoprotein $\mathrm{E}$ immunoreactivity in cerebral amyloid deposits and neurofibrillary tangles in Alzheimer's disease and kuru plaque amyloid in Creutzfeldt-Jakob disease. Brain Res 541:163-166, 1991.

101. Arelin K, Kinoshita A, Whelan CM, Irizarry MC, Rebeck GW, Strickland DK, et al. LRP and senile plaques in Alzheimer's disease: colocalization with apolipoprotein $\mathrm{E}$ and with activated astrocytes. Mol Brain Res 104:38-46, 2002.

102. Masliah E, Mallory M, Ge N, Alford M, Veinbergs I, Roses AD. Neurodegeneration in the central nervous system of apoE-deficient mice. Exp Neurol 136:107-122, 1995.

103. Masliah E, Samuel W, Veinbergs I, Mallory M, Mante M, Saitoh T. Neurodegeneration and cognitive impairment in apoE-deficient mice is ameliorated by infusion of recombinant apoE. Brain Res 751:307-314, 1997

104. Gordon I, Grauer E, Genis I, Sehayek E, Michaelson DM. Memory deficits and cholinergic impairments in apolipoprotein E-deficient mice. Neurosci Lett 199:1-4, 1995.

105. Irizarry MC, Rebeck GW, Cheung B, Bales K, Paul SM, Holzman D, et al. Modulation of A $\beta$ deposition in APP transgenic mice by an apolipoprotein E null background. Ann NY Acad Sci 920:171-178, 2000.

106. Bales KR, Verina T, Dodel RC, Du Y, Altstiel L, Bender M, et al. Lack of apolipoprotein $\mathrm{E}$ dramatically reduces amyloid $\beta$-peptide deposition. Nat Genet 17:263-264, 1997.

107. Bales KR, Verina T, Cummins DJ, Du Y, Dodel RC, Saura J, et al. Apolipoprotein $\mathrm{E}$ is essential for amyloid deposition in the APP(V717F) transgenic mouse model of Alzheimer's disease. Proc Natl Acad Sci USA 96:15233-15238, 1999.

108. Holtzman DM, Fagan AM, Mackey B, Tenkova T, Sartorius L, Paul SM, et al. Apolipoprotein E facilitates neuritic and cerebrovascular plaque formation in an Alzheimer's disease model. Ann Neurol 47:739-747, 2000.

109. Holtzman DM, Bales KR, Tenkova T, Fagan AM, Parsadanian $\mathrm{M}$, Sartorius LJ, et al. Apolipoprotein E isoform-dependent amyloid deposition and neuritic degeneration in a mouse model of Alzheimer's disease. Proc Natl Acad Sci USA 97:2892-2897, 2000.

110. Irizarry MC, Cheung BS, Rebeck GW, Paul SM, Bales KR, Hyman BT. Apolipoprotein E affects the amount, form, and anatomical distribution of amyloid $\beta$-peptide deposition in homozygous APP(V717F) transgenic mice. Acta Neuropathol (Berl) 100: $451-458,2000$

111. Fryer JD, Taylor JW, DeMattos RB, Bales KR, Paul SM, Parsadanian $\mathrm{M}$, et al. Apolipoprotein E markedly facilitates agedependent cerebral amyloid angiopathy and spontaneous hemorrhage in amyloid precursor protein transgenic mice. $J$ Neurosci 23:7889-7896, 2003.

112. Mann KM, Thorngate FE, Katoh-Fukui Y, Hamanaka H, Williams DL, Fujita S, et al. Independent effects of APOE on cholesterol metabolism and brain $\mathrm{A} \beta$ levels in an Alzheimer disease mouse model. Hum Mol Genet 13:1959-1968, 2004.

113. Van Uden E, Mallory M, Veinbergs I, Alford M, Rockenstein E, Masliah E. Increased extracellular amyloid deposition and neurodegeneration in human amyloid precursor protein transgenic mice deficient in receptor-associated protein. $J$ Neurosci 22:9298-9304, 2002.

114. Luo Y, Bolon B, Kahn S, Bennett BD, Babu-Khan S, Denis P, et al. Mice deficient in BACE1, the Alzheimer's $\beta$-secretase, have normal phenotype and abolished $\beta$-amyloid generation. $\mathrm{Nat} \mathrm{Neu}$ rosci 4:231-232, 2001.

115. Cai H, Wang Y, McCarthy D, Wen H, Borchelt DR, Price DL, et al. $\mathrm{BACE} 1$ is the major $\beta$-secretase for generation of $\mathrm{A} \beta$ peptides by neurons. Nat Neurosci 4:233-234, 2001.

116. Harrison SM, Harper AJ, Hawkins J, Duddy G, Grau E, Pugh PL, et al. BACE1 ( $\beta$-secretase) transgenic and knockout mice: identification of neurochemical deficits and behavioral changes. Mol Cell Neurosci 24:646-655, 2003.

117. Luo Y, Bolon B, Damore MA, Fitzpatrick D, Liu H, Zhang J, et al. BACE1 ( $\beta$-secretase) knockout mice do not acquire compensatory gene expression changes or develop neural lesions over time. Neurobiol Dis 14:81-88, 2003.

118. Mohajeri MH, Saini KD, Nitsch RM. Transgenic BACE expression in mouse neurons accelerates amyloid plaque pathology. J Neural Transm 111:413-425, 2004.

119. Friedhoff P, von Bergen M, Mandelkow EM, Mandelkow E. Structure of tau protein and assembly into paired helical filaments. Biochim Biophys Acta 1502:122-132, 2000.

120. Morishima-Kawashima M, Ihara Y. Alzheimer's disease: $\beta$-amyloid protein and tau. J Neurosci Res 70:392-401, 2002.

121. Hutton M, Lendon CL, Rizzu P, Baker M, Froelich S, Houlden H, et al. Association of missense and $5^{\prime}$-splice-site mutations in tau with the inherited dementia FTDP-17. Nature 393:702-705, 1998.

122. Gotz J, Probst A, Spillantini MG, Schafer T, Jakes R, Burki K, et al. Somatodendritic localization and hyperphosphorylation of tau protein in transgenic mice expressing the longest human brain tau isoform. EMBO J 14:1304-1313, 1995.

123. Gotz J, Barmettler R, Ferrari A, Goedert M, Probst A, Nitsch RM. In vivo analysis of wild-type and FTDP-17 tau transgenic mice. Ann NY Acad Sci 920:126-133, 2000.

124. Probst A, Gotz J, Wiederhold KH, Tolnay M, Mistl C, Jaton AL, et al. Axonopathy and amyotrophy in mice transgenic for human four-repeat tau protein. Acta Neuropathol (Berl) 99:469-481, 2000.

125. Spittaels K, Van den Haute C, Van Dorpe J, Bruynseels K, Vandezande K, Laenen I, et al. Prominent axonopathy in the brain and spinal cord of transgenic mice overexpressing four-repeat human tau protein. Am J Pathol 155:2153-2165, 1999.

126. Rouleau GA, Clark AW, Rooke K, Pramatarova A, Krizus A, Suchowersky O, et al. SOD1 mutation is associated with accumulation of neurofilaments in amyotrophic lateral sclerosis. Ann Neurol 39:128-131, 1996.

127. Ishihara T, Zhang B, Higuchi M, Yoshiyama Y, Trojanowski JQ, Lee VM. Age-dependent induction of congophilic neurofibrillary tau inclusions in tau transgenic mice. Am J Pathol 158:555-562, 2001.

128. Duff K, Knight H, Refolo LM, Sanders S, Yu X, Picciano M, et al. Characterization of pathology in transgenic mice over-expressing human genomic and cDNA tau transgenes. Neurobiol Dis 7:87-98, 2000.

129. Andorfer C, Kress Y, Espinoza M, de Silva R, Tucker KL, Barde YA, et al. Hyperphosphorylation and aggregation of tau in mice expressing normal human tau isoforms. $J$ Neurochem 86:582$590,2003$.

130. Lewis J, McGowan E, Rockwood J, Melrose H, Nacharaju P, Van Slegtenhorst M, et al. Neurofibrillary tangles, amyotrophy and progressive motor disturbance in mice expressing mutant (P301L) tau protein. Nat Genet 25:402-405, 2000.

131. Arendash GW, Lewis J, Leighty RE, McGowan E, Cracchiolo JR, Hutton M, et al. Multi-metric behavioral comparison of APPsw and P301L models for Alzheimer's disease: linkage of poorer cognitive performance to tau pathology in forebrain. Brain Res 1012:29-41, 2004

132. Gotz J, Chen F, Barmettler R, Nitsch RM. Tau filament formation in transgenic mice expressing P301L tau. J Biol Chem 276:529534, 2001.

133. Santa Cruz KS, Paulson J, Lewis J, Mariash A, Forster C, Guimaraes A, et al. Cell loss and gliosis in a transgenic mouse with regulatable P301L tau overexpression. Poster 840.25 presented at the Society for Neuroscience meeting, New Orleans, LA, 2003. 
134. Allen B, Ingram E, Takao M, Smith MJ, Jakes R, Virdee K, et al. Abundant tau filaments and nonapoptotic neurodegeneration in transgenic mice expressing human P301S tau protein. $J$ Neurosci 22:9340-9351, 2002.

135. Gotz J, Chen F, van Dorpe J, Nitsch RM. Formation of neurofibrillary tangles in P3011 tau transgenic mice induced by A $\beta 42$ fibrils. Science 293:1491-1495, 2001.

136. Lewis J, Dickson DW, Lin WL, Chisholm L, Corral A, Jones G, et al. Enhanced neurofibrillary degeneration in transgenic mice expressing mutant tau and APP. Science 293:1487-1491, 2001.

137. Oddo S, Caccamo A, Shepherd JD, Murphy MP, Golde TE, Kayed R, et al. Triple-transgenic model of Alzheimer's disease with plaques and tangles: intracellular $\mathrm{A} \beta$ and synaptic dysfunction. Neuron 39:409-421, 2003.

138. Oddo S, Caccamo A, Kitazawa M, Tseng BP, LaFerla FM. Amyloid deposition precedes tangle formation in a triple transgenic model of Alzheimer's disease. Neurobiol Aging 24:1063-1070, 2003.

139. Brecht WJ, Harris FM, Chang S, Tesseur I, Yu GQ, Xu Q, et al. Neuron-specific apolipoprotein e4 proteolysis is associated with increased tau phosphorylation in brains of transgenic mice. $\mathrm{J} \mathrm{Neu}$ rosci 24:2527-2534, 2004.

140. Lucas JJ, Hernandez F, Gomez-Ramos P, Moran MA, Hen R, Avila J Decreased nuclear $\beta$-catenin, tau hyperphosphorylation and neurodegeneration in GSK-3 $\beta$ conditional transgenic mice. EMBO J 20:27-39, 2001

141. Ahlijanian MK, Barrezueta NX, Williams RD, Jakowski A, Kowsz KP, McCarthy S, et al. Hyperphosphorylated tau and neurofilament and cytoskeletal disruptions in mice overexpressing human p25, an activator of cdk5. Proc Natl Acad Sci USA 97:2910-2915, 2000.

142. Noble W, Olm V, Takata K, Casey E, Mary O, Meyerson J, et al. Cdk5 is a key factor in tau aggregation and tangle formation in vivo. Neuron 38:555-565, 2003.

143. Kins S, Crameri A, Evans DR, Hemmings BA, Nitsch RM, Gotz J Reduced protein phosphatase $2 \mathrm{~A}$ activity induces hyperphosphorylation and altered compartmentalization of tau in transgenic mice. J Biol Chem 276:38193-38200, 2001.

144. Lu PJ, Wulf G, Zhou XZ, Davies P, Lu KP. The prolyl isomerase Pin1 restores the function of Alzheimer-associated phosphorylated tau protein. Nature 399:784-788, 1999.

145. Liou YC, Sun A, Ryo A, Zhou XZ, Yu ZX, Huang HK, et al. Role of the prolyl isomerase Pin1 in protecting against age-dependent neurodegeneration. Nature 424:556-561, 2003.

146. Rosen DR, Martin-Morris L, Luo LQ, White K. A Drosophila gene encoding a protein resembling the human $\beta$-amyloid protein precursor. Proc Natl Acad Sci USA 86:2478-2482, 1989.

147. Daigle I, Li C. apl-1, a Caenorhabditis elegans gene encoding a protein related to the human $\beta$-amyloid protein precursor. Proc Natl Acad Sci USA 90:12045-12049, 1993.

148. Gunawardena S, Goldstein LS. Disruption of axonal transport and neuronal viability by amyloid precursor protein mutations in Drosophila. Neuron 32:389-401, 2001.

149. Link CD. Expression of human $\beta$-amyloid peptide in transgenic Caenorhabditis elegans. Proc Natl Acad Sci USA 92:9368-9372, 1995.

150. Fay DS, Fluet A, Johnson CJ, Link CD. In vivo aggregation of $\beta$-amyloid peptide variants. $J$ Neurochem 71:1616-1625, 1998.

151. Fonte V, Kapulkin V, Taft A, Fluet A, Friedman D, Link CD. Interaction of intracellular $\beta$ amyloid peptide with chaperone proteins. Proc Natl Acad Sci USA 99:9439-9444, 2002.

152. Levitan D, Greenwald I. Facilitation of lin-12-mediated signalling by sel-12, a Caenorhabditis elegans S182 Alzheimer's disease gene. Nature 377:351-354, 1995.

153. Boulianne GL, Livne-Bar I, Humphreys JM, Liang Y, Lin C, Rogaev E, et al. Cloning and characterization of the Drosophila presenilin homologue. Neuroreport 8:1025-1029, 1997.

154. Li X, Greenwald I. HOP-1, a Caenorhabditis elegans presenilin, appears to be functionally redundant with SEL-12 presenilin and to facilitate LIN-12 and GLP-1 signaling. Proc Natl Acad Sci USA 94:12204-12209, 1997.

155. Hong CS, Koo EH. Isolation and characterization of Drosophila presenilin homolog. Neuroreport 8:665-668, 1997.
156. Chung HM, Struhl G. Nicastrin is required for Presenilin-mediated transmembrane cleavage in Drosophila. Nat Cell Biol 3:1129-1132, 2001.

157. Goutte C, Tsunozaki M, Hale VA, Priess JR. APH-1 is a multipass membrane protein essential for the Notch signaling pathway in Caenorhabditis elegans embryos. Proc Natl Acad Sci USA 99:775-779, 2002.

158. Francis R, McGrath G, Zhang J, Ruddy DA, Sym M, Apfeld J, et al. aph-1 and pen- 2 are required for Notch pathway signaling, $\gamma$-secretase cleavage of $\beta \mathrm{APP}$, and presenilin protein accumulation. Dev Cell 3:85-97, 2002.

159. Wittmann CW, Wszolek MF, Shulman JM, Salvaterra PM, Lewis J, Hutton M, et al. Tauopathy in Drosophila: neurodegeneration without neurofibrillary tangles. Science 293:711-714, 2001.

160. Jackson GR, Wiedau-Pazos M, Sang TK, Wagle N, Brown CA, Massachi S, et al. Human wild-type tau interacts with wingless pathway components and produces neurofibrillary pathology in Drosophila. Neuron 34:509-519, 2002.

161. Torroja L, Chu H, Kotovsky I, White K. Neuronal overexpression of APPL, the Drosophila homologue of the amyloid precursor protein (APP), disrupts axonal transport. Curr Biol 9:489-492, 1999.

162. Kraemer BC, Zhang B, Leverenz JB, Thomas JH, Trojanowski JQ, Schellenberg GD. Neurodegeneration and defective neurotransmission in a Caenorhabditis elegans model of tauopathy. Proc Natl Acad Sci USA 100:9980-9985, 2003.

163. Hall GF, Cohen MJ. Extensive dendritic sprouting induced by close axotomy of central neurons in the lamprey. Science 222: $518-521,1983$.

164. Hall GF, Lee VM, Lee G, Yao J Staging of neurofibrillary degeneration caused by human tau overexpression in a unique cellular model of human tauopathy. Am J Pathol 158:235-246, 2001.

165. Hall GF, Lee S, Yao J. Neurofibrillary degeneration can be arrested in an in vivo cellular model of human tauopathy by application of a compound which inhibits tau filament formation in vitro. J Mol Neurosci 19:253-260, 2002.

166. Dovey HF, John V, Anderson JP, Chen LZ, de Saint Andrieu P, Fang LY, et al. Functional $\gamma$-secretase inhibitors reduce $\beta$-amyloid peptide levels in brain. J Neurochem 76:173-181, 2001.

167. Lanz TA, Himes CS, Pallante G, Adams L, Yamazaki S, Amore $\mathrm{B}$, et al. The $\gamma$-secretase inhibitor $\mathrm{N}$-[N-(3,5-difluorophenacetyl)L-alanyl]-S-phenylglycine t-butyl ester reduces $A \beta$ levels in vivo in plasma and cerebrospinal fluid in young (plaque-free) and aged (plaque-bearing) Tg2576 mice. J Pharmacol Exp Ther 305:864871, 2003.

168. De Strooper B, Annaert W, Cupers P, Saftig P, Craessaerts K, Mumm JS, et al. A presenilin-1-dependent $\gamma$-secretase-like protease mediates release of Notch intracellular domain. Nature 398: $518-522,1999$.

169. Wong GT, Manfra D, Poulet FM, Zhang Q, Josien H, Bara T, et al. Chronic treatment with the $\gamma$-secretase inhibitor LY-411,575 inhibits $\beta$-amyloid peptide production and alters lymphopoiesis and intestinal cell differentiation. $J$ Biol Chem 279:12876-12882, 2004.

170. Yan Q, Zhang J, Liu H, Babu-Khan S, Vassar R, Biere AL, et al. Anti-inflammatory drug therapy alters $\beta$-amyloid processing and deposition in an animal model of Alzheimer's disease. $J$ Neurosci 23:7504-7509, 2003.

171. Lleo A, Berezovska O, Herl L, Raju S, Deng A, Bacskai BJ, et al. Nonsteroidal anti-inflammatory drugs lower $A \beta 42$ and change presenilin 1 conformation. 10:1065-1066, 2004

172. Eriksen JL, Sagi SA, Smith TE, Weggen S, Das P, McLendon DC, et al. NSAIDs and enantiomers of flurbiprofen target $\gamma$-secretase and lower $\mathrm{A} \beta 42$ in vivo. $J$ Clin Invest 112:440-449, 2003.

173. Citron M. $\beta$-Secretase inhibition for the treatment of Alzheimer's disease-promise and challenge. Trends Pharmacol Sci 25:9297, 2004.

174. Gnjec A, Fonte JA, Atwood C, Martins RN. Transition metal chelator therapy-a potential treatment for Alzheimer's disease? Front Biosci 7:d1016-d1023, 2002.

175. Cherny RA, Atwood CS, Xilinas ME, Gray DN, Jones WD, McLean CA, et al. Treatment with a copper-zinc chelator mark- 
edly and rapidly inhibits $\beta$-amyloid accumulation in Alzheimer's disease transgenic mice. Neuron 30:665-676, 2001.

176. Lee JY, Cole TB, Palmiter RD, Suh SW, Koh JY. Contribution by synaptic zinc to the gender-disparate plaque formation in human Swedish mutant APP transgenic mice. Proc Natl Acad Sci USA 99:7705-7710, 2002.

177. Ritchie CW, Bush AI, Mackinnon A, Macfarlane S, Mastwyk M, MacGregor L, et al. Metal-protein attenuation with iodochlorhydroxyquin (clioquinol) targeting $\mathrm{A} \beta$ amyloid deposition and toxicity in Alzheimer disease: a pilot phase 2 clinical trial. Arch Neurol 60:1685-1691, 2003.

178. Schenk D, Barbour R, Dunn W, Gordon G, Grajeda H, Guido T, et al. Immunization with amyloid- $\beta$ attenuates Alzheimer-disease-like pathology in the PDAPP mouse. Nature 400:173-177, 1999.

179. Bard F, Cannon C, Barbour R, Burke RL, Games D, Grajeda H, et al. Peripherally administered antibodies against amyloid $\beta$-peptide enter the central nervous system and reduce pathology in a mouse model of Alzheimer disease. Nat Med 6:916-919, 2000.

180. Dodart JC, Bales KR, Gannon KS, Greene SJ, DeMattos RB, Mathis $C$, et al. Immunization reverses memory deficits without reducing brain $\mathrm{A} \beta$ burden in Alzheimer's disease model. Nat Neurosci 5:452-457, 2002.

181. Janus C, Pearson J, McLaurin J, Mathews PM, Jiang Y, Schmidt $\mathrm{SD}$, et al. A $\beta$ peptide immunization reduces behavioural impairment and plaques in a model of Alzheimer's disease. Nature 408:979-982, 2000.

182. Morgan D, Diamond DM, Gottschall PE, Ugen KE, Dickey C, Hardy J, et al. A $\beta$ peptide vaccination prevents memory loss in an animal model of Alzheimer's disease. Nature 408:982-985, 2000.

183. D'Amore JD, Kajdasz ST, McLellan ME, Bacskai BJ, Stern EA, Hyman BT. In vivo multiphoton imaging of a transgenic mouse model of Alzheimer disease reveals marked thioflavine-S-associated alterations in neurite trajectories. J Neuropathol Exp Neurol 62:137-145, 2003.
184. Lombardo JA, Stern EA, McLellan ME, Kajdasz ST, Hickey GA, Bacskai BJ, et al. Amyloid- $\beta$ antibody treatment leads to rapid normalization of plaque-induced neuritic alterations. $J$ Neurosci 23:10879-10883, 2003.

185. Oddo S, Billings L, Kesslak JP, Cribbs DH, LaFerla FM. A $\beta$ immunotherapy leads to clearance of early, but not late, hyperphosphorylated tau aggregates via the proteasome. Neuron 43 : 321-332, 2004

186. Orgogozo JM, Gilman S, Dartigues JF, Laurent B, Puel M, Kirby LC, et al. Subacute meningoencephalitis in a subset of patients with AD after A $\beta 42$ immunization. Neurology 61:46-54, 2003.

187. Nicoll JA, Wilkinson D, Holmes C, Steart P, Markham H, Weller RO. Neuropathology of human Alzheimer disease after immunization with amyloid- $\beta$ peptide: a case report. Nat Med 9:448452, 2003.

188. Ferrer I, Boada Rovira M, Sanchez Guerra ML, Rey MJ, CostaJussa F. Neuropathology and pathogenesis of encephalitis following amyloid- $\beta$ immunization in Alzheimer's disease. Brain Pathol 14:11-20, 2004.

189. Hock C, Konietzko U, Streffer JR, Tracy J, Signorell A, MullerTillmanns B, et al. Antibodies against $\beta$-amyloid slow cognitive decline in Alzheimer's disease. Neuron 38:547-554, 2003.

190. Lesne S, Docagne F, Gabriel C, Liot G, Lahiri DK, Buee L, et al. Transforming growth factor- $\beta 1$ potentiates amyloid- $\beta$ generation in astrocytes and in transgenic mice. J Biol Chem 278:1840818418, 2003.

191. Wyss-Coray T, Lin C, Yan F, Yu GQ, Rohde M, McConlogue L, et al. TGF- $\beta 1$ promotes microglial amyloid- $\beta$ clearance and reduces plaque burden in transgenic mice. Nat Med 7:612-618, 2001.

192. Wyss-Coray T, Masliah E, Mallory M, McConlogue L, JohnsonWood K, Lin C, et al. Amyloidogenic role of cytokine TGF- $\beta 1$ in transgenic mice and in Alzheimer's disease. Nature 389:603606, 1997. 